\title{
Hydrogen Production Technologies Overview
}

\author{
Mostafa El-Shafie*, Shinji Kambara, Yukio Hayakawa \\ Environmental and Renewable Energy Systems Division, Gifu University, Gifu City, Japan \\ Email: *mostafaelshafie81@gmail.com
}

How to cite this paper: El-Shafie, M., Kambara, S. and Hayakawa, Y. (2019) Hydrogen Production Technologies Overview. Journal of Power and Energy Engineering, 7, 107-154.

https://doi.org/10.4236/jpee.2019.71007

Received: December 5, 2018

Accepted: January 25, 2019

Published: January 28, 2019

Copyright $\odot 2019$ by author(s) and Scientific Research Publishing Inc. This work is licensed under the Creative Commons Attribution International License (CC BY 4.0).

http://creativecommons.org/licenses/by/4.0/

(c) (7) Open Access

\begin{abstract}
Hydrogen energy became the most significant energy as the current demand gradually starts to increase. Hydrogen energy is an important key solution to tackle the global temperature rise. The key important factor of hydrogen production is the hydrogen economy. Hydrogen production technologies are commercially available, while some of these technologies are still under development. This paper reviews the hydrogen production technologies from both fossil and non-fossil fuels such as (steam reforming, partial oxidation, auto thermal, pyrolysis, and plasma technology). Additionally, water electrolysis technology was reviewed. Water electrolysis can be combined with the renewable energy to get eco-friendly technology. Currently, the maximum hydrogen fuel productions were registered from the steam reforming, gasification, and partial oxidation technologies using fossil fuels. These technologies have different challenges such as the total energy consumption and carbon emissions to the environment are still too high. A novel non-fossil fuel method [ammonia $\mathrm{NH}_{3}$ ] for hydrogen production using plasma technology was reviewed. Ammonia decomposition using plasma technology without and with a catalyst to produce pure hydrogen was considered as compared case studies. It was showed that the efficiency of ammonia decomposition using the catalyst was higher than ammonia decomposition without the catalyst. The maximum hydrogen energy efficiency obtained from the developed ammonia decomposition system was $28.3 \%$ with a hydrogen purity of $99.99 \%$. The development of ammonia decomposition processes is continues for hydrogen production, and it will likely become commercial and be used as a pure hydrogen energy source.
\end{abstract}

\section{Keywords}

Hydrogen Technology, Hydrogen Production, Steam Reforming, Plasma, Ammonia Decomposition

\section{Introduction}

Energy is the most important needs for the human life and development of the 
worldwide. So, energy is the world key consideration in all discussions and meetings of the sustainable energy development. The renewable energy sources, such as solar energy, wind energy, waves, and tides energy are considered eco-friendly. It is expected that the hydrogen fuel and its demand will rise rapidly over the next few decades [1] [2]. The hydrogen energy utilization, as an energy source and storage methods, has been reviewed [3]. The recycling of the waste materials to useful energy sources through waste-to-energy technologies such as hydrogen, biogas, etc., has been reviewed [4]. The importance of hydrogen fuel is known as alternative clean energy and to overcome the fossil fuels depletion due to the high extension usage. In addition, fossil fuels have a bad effect on the environment due to combustion product gases such as carbon oxides, nitrogen, sulfur, etc. which have the main responsibilities of the global warming [5]. Hydrogen fuel is considered the alternative clean energy fuel and it can be produced from eco-friendly sources. In the current state, it is investigated that too little quantity of hydrogen is produced from the renewable energy resources through water electrolysis and the highest quantity is still generated from fossil fuels [6] [7]. Due to the hydrogen fuel advantages and versatility, in the long-term hydrogen will be the alternative of hydrocarbons fuels [8]. Also, hydrogen fuel is considered the highest efficient and clean energy carrier which produced water only as a by-product of its combustion. The worldwide is accepted to use hydrogen fuel as an independent clean energy source and high energy content compared to the fossil fuels, Table 1 is shown the energy content of different fuels resources [9].

In different energy applications such as fuel cells, hydrogen energy can be utilized as a clean energy source without $\mathrm{CO}_{2}$ products emission to the environment which water is the outlet combustion products. It has been investigated that the nitrogen oxides gases are produced in the high temperature hydrogen combustion, but these environmental pollutants can be removed at the low

Table 1. Energy contents of different fuels [9].

\begin{tabular}{cc}
\hline Fuel & Energy content $(\mathrm{MJ} / \mathrm{kg})$ \\
\hline Hydrogen & 120 \\
Liquefied natural gas & 54.4 \\
Propane & 49.6 \\
Aviation gasoline & 46.8 \\
Automotive gasoline & 46.4 \\
Automotive diesel & 45.6 \\
Ethanol & 29.6 \\
Methanol & 19.7 \\
Coke & 27 \\
Wood(dry) & 16.2 \\
Begasse & 9.6 \\
\hline
\end{tabular}


temperature usage such as fuel cells [10]. The power-to-gas pilot plants have been used to generate electricity from hydrogen fuel or feeding the hydrogen gas into the gas distribution system [11] [12]. Currently, this technology is used for storing power in some European countries as a hydrogen gas [13] [14] [15] [16] [17]. In most power-to-gas pilot plants in Germany, the wind energy, and solar energy is used to produce electricity [18]. Many studies have been developed to evaluate the challenges of transition of using the hydrogen economy [19]-[48]. The steps which involved the implementation of a hydrogen economy have been investigated [49] [50] [51] [52]. The hydrogen energy prospects have been described to avoid the climate change-related problems [53]. The rationale of the hydrogen energy systems and technology has been studied including the present energy systems and their environmental impact [3] [54]-[63]. In this article, the hydrogen gas production technologies from the fossil and non-fossil fuels such as steam reforming process, water electrolysis process... etc. are reviewed. A novel hydrogen gas production method using ammonia decomposition by plasma technology is reviewed. Ammonia decomposition using plasma technology without and with the catalyst to produce pure hydrogen is considered as compared case studies.

\subsection{World Energy Consumption}

As global population increases and the urbanization trend continues, the energy consumers will become ever more and recently, the International Energy Agency report is predicted that the global energy demand will increase by 2030 to $50 \%$ [64]. Due to the fossil fuels limited nature and depletion, research and development have extensively started on generating new alternative sources and study the efficiently use of the current fossil fuels. The percentage of the power consumption of different humanities applications such as the building power consumption was considered the main energy usage and acts $51 \%$ of the total energy consumption [65]. The world population is estimated that will be triple by 2030 . The common Energy Gases begins with natural gas or methane which has only one carbon and four hydrogen atoms. The world has been started to convert energy from one energy form to another form. The transition of solids to liquids to gases has been illustrated in Figure 1 by GHK Company [66].

Before the mid of $19^{\text {th }}$ century, the most reliance energy of the world was from wood. Coal has still remained the main reliable of the world energy in the 19th century. The energy usage was growing rapidly due to the high increase in world population, the world is directed toward oil fuel which overcomes the coal energy problems. But oil fuel is now facing environmental problems and the world is directed to use natural gas fuel. It has solved most of the environmental problems due to it is cleaner, lighter and more efficiently. Also, the distribution can be through a pipe network that is less conspicuous and more extensive than oil fuel. Nowadays, natural gas fuel became the first choice for generating electricity. The renewable energy ratio generated the electric energy and the renewable 


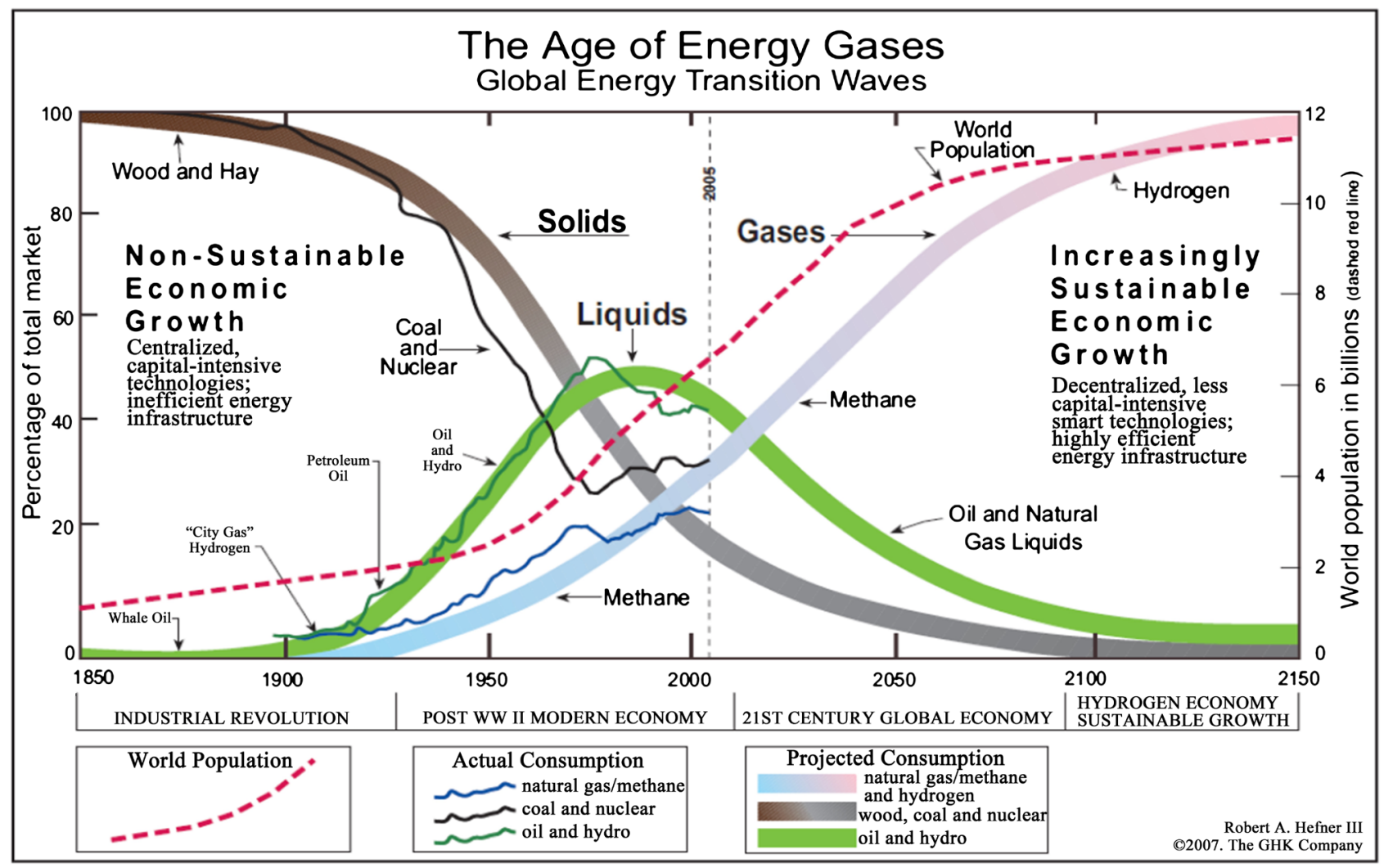

Figure 1. Global energy system transition, from 1850-2150 [66].

energy development has been compared by Japan energy 2017 [67]. Firstly, the world energy consumption rate is investigated to show the importance of increasing renewables energy through increasing energy efficiency and switching it to be clean, low carbon resources and economic growth is required. The increasing of fossil fuel usage the increasing of air pollution growing with a possibility of a highly serious economic and negative environmental effect [68] [69].

\subsection{Environmental Impact}

Hydrogen is the highest clean energy carrier which it can be used in the most energy applications such as generates electricity and transportation. Hydrogen fuel energy is expected to be the highest energy carrier's usage in the future; many advantages have been investigated that it can be used in transportation, long time storage and low environmental impact [70]. Figure 2 is presented the greenization factor (GF), the environmental impact factor (EIF) and the hydrogen content factor (HCF) of the different energy fuels (coal, oil, natural gas, and hydrogen) [71]. In order to take the hydrogen fuel advantages, the hydrogen economy is still the most important hydrogen production issue. So, the renewable energy sources should be used to produce hydrogen at low costs. The assessment methodology for hydrogen production methods has been implemented to study the environmental impact [72] [73]. Hydrogen fuel has been considered that to be the highest clean and renewable future energy source [74]. A comparative 


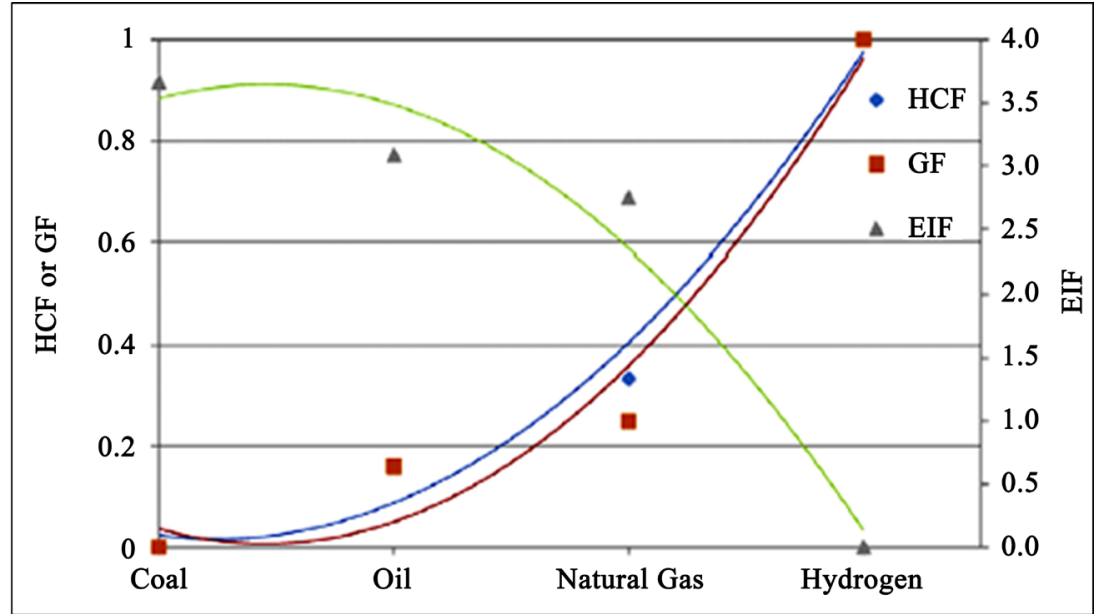

Figure 2. Hydrogen Content Factor (HCF), Greenization Factor (GF), and Environmental Impact Factor (EIF) of hydrogen and other fossil fuels [71].

study has been developed to reduce the total environmental emissions from the marine transportations by using hydrogen fuel [75] [76].

\section{Hydrogen Production Technology}

Hydrogen gas became the most important fuel which can be used as an alternative feedstock in industrial application processes. As the utilization of hydrogen fuel grows as the global warming temperature still keeps rising, so, the hydrogen production should be on a large scale. The evaluation of hydrogen production methods has been studied in different reviews [56] [71] [77]-[89]. Currently, the main source of hydrogen production is based on the fossil fuels. It can be presented as a commercial mature technology which it can be applied at low costs and get high efficiencies [90]. The hydrogen production especially using the steam reforming process of methane can get the efficiency range of (65\% - 75\%). On the other hand, the efficiency of the partial oxidation process of methane is recorded about 50\% [54]. Hydrogen gas can also produce from water using the water electrolysis method which acting about $95 \%$ of the total quantity of hydrogen produced [91]. In the next section of this article, we will present several methods of the hydrogen production technologies. Recently, Plasma technology is an important method to produce the hydrogen fuel using hydrocarbons or alcohols. Hydrogen production using ammonia decomposition is a novel method can be established to produce pure hydrogen by using the plasma membrane reactor. A comparison of two different ammonia decomposition methods using the plasma technology is developed. The hydrogen production technology can be divided into hydrocarbons reforming and non-hydrocarbons reforming technology [80]. Firstly, a brief review is conducted to describe the hydrogen production from non-hydrocarbons technology.

\subsection{Water Electrolysis}

It can be defined in the simplest form by using two electrodes in water and 
passing the electrical current water is converted into hydrogen and oxygen. The water electrolysis method can be divided into three different types of the electrolyte alkaline, proton exchange membrane (PEM), and solid oxide electrolysers (SOE) [92]. Table 2 has been listed the typical specifications of the water electrolysis technologies methods. The commercial low temperature electrolysers were developed and have efficiencies of (56\% - 73\%) at conditions of (70.1 - 53.4 $\mathrm{kWh} \cdot \mathrm{kg}^{-1} \mathrm{H} 2$ at $1 \mathrm{~atm}$ and $25^{\circ} \mathrm{C}$ ) [93]. The proton exchange membrane (PEM) electrolysis and solid oxide electrolysis (SOE) units have been studied [94] [95] [96]. Alkaline electrolysis systems are the most commonly compared to other water electrolysis methods. Solid oxide electrolysis (SOE) is the most electrically efficient but still are under development. Corrosion, seals, thermal cycling, and chrome migration are the major challenges faced by the SOE technology. The Proton exchange membrane (PEM) electrolysis systems are more efficient than alkaline electrolyser. Also, the corrosion and seals issues don't exist as (SOE), but the cost of (PEM) is too high compared with alkaline electrolysers systems. Alkaline electrolyser systems have the lowest capital cost and have the lowest efficiency so the electrical energy cost is too high. Recently, electrolysers are used for producing pure hydrogen and high pressure units have been developed [97]. The advantage of using the high pressure operation unit is to eliminate using expensive hydrogen compressors. The hydrogen production using the water electrolysis systems are showed the too high cost to generate hydrogen on large scale using the water electrolysis method. Additionally, the water electrolysis

Table 2. The typical specifications of alkaline, PEM and SOE [103].

\begin{tabular}{|c|c|c|c|}
\hline Specification & Alkaline & PEM & SOE \\
\hline Technology maturity & State of the art & Demonstration & $\mathrm{R} \& \mathrm{D}$ \\
\hline Cell temperature, ${ }^{\circ} \mathrm{C}$ & $60-80$ & $50-80$ & $900-1000$ \\
\hline Cell pressure, bar & $<30$ & $<30$ & $<30$ \\
\hline Current density, $\mathrm{A} / \mathrm{cm}^{2}$ & $0.2-0.4$ & $0.6-2.0$ & $0.3-1.0$ \\
\hline Cell voltage, $\mathrm{V}$ & $1.8-2.4$ & $1.8-2.2$ & $0.95-1.3$ \\
\hline Power density, $\mathrm{W} / \mathrm{cm}^{2}$ & Up to 1.0 & Up to 4.4 & - \\
\hline Voltage efficiency, \% & $62-82$ & $67-82$ & $81-86$ \\
\hline $\begin{array}{l}\text { Specific system energy consumption, } \\
\qquad \mathrm{kWh} / \mathrm{Nm}^{2}\end{array}$ & $4.5-7.0$ & $4.5-7.5$ & $2.5-3.5$ \\
\hline Partial load range, $\%$ & $20-40$ & $0-10$ & - \\
\hline Cell area, $\mathrm{m}^{2}$ & $<4$ & $<300$ & - \\
\hline Hydrogen production, $\mathrm{Nm}^{2} / \mathrm{hr}$ & $<760$ & $<30$ & - \\
\hline Stack lifetime, hr & $<90,000$ & $<20,000$ & $<40,000$ \\
\hline System lifetime, yr & $20-30$ & $10-20$ & - \\
\hline Hydrogen purity, \% & $>99.8$ & 99.999 & - \\
\hline Cold start-up time, min & 15 & $<15$ & $>60$ \\
\hline
\end{tabular}


systems are utilized the non-renewable power generation source to produce electricity for the water electrolysis systems [98] [99] [100] [101] [102].

\subsubsection{Alkaline Electrolyser}

This type is commonly used on the large-scale systems. Alkali solutions are divided into two different electrolyte types. The first electrolyte type is potassium hydroxide $(\mathrm{KOH})$ with a weight percent of $(20 \%$ - 40\%) [104]. Sodium hydroxide $(\mathrm{NaOH})$ and sodium chloride $(\mathrm{NaCl})$ have been used as the other alkaline electrolyte types [105]. The separating diaphragm between the two electrodes is made of the asbestos material with a thickness of $3 \mathrm{~mm}$ and due to the usage of the asbestos materials the water electrolyser operation temperature is limited to be $80^{\circ} \mathrm{C}$ [103]. Hydrogen and hydroxide are generated at the cathode part, then the hydroxide is moved to the anode part generating oxygen. The anode and cathode part reactions can be expressed as follows:

- Anode reaction:

$$
4 \mathrm{OH}^{-} \rightarrow \mathrm{O}_{2}+2 \mathrm{H}_{2} \mathrm{O}
$$

- Cathode reaction:

$$
2 \mathrm{H}_{2} \mathrm{O}+2 \mathrm{e}^{-} \rightarrow \mathrm{H}_{2}+2 \mathrm{OH}^{-}
$$

- The overall equation is:

$$
\mathrm{H}_{2} \mathrm{O} \rightarrow \mathrm{H}_{2}+\frac{1}{2} \mathrm{O}_{2} \quad \Delta H=-288\left[\mathrm{~kJ} \cdot \mathrm{mol}^{-1}\right]
$$

The gas-liquid separation unit is used to separate the generated hydrogen gas outside the electrolyser [106]. The alkaline electrolysers process efficiencies have been registered in a range of $(50 \%-60 \%)$ at a current density of (100 - 300 $\mathrm{mA} \cdot \mathrm{cm}^{-2}$ ) and at the hydrogen gas lower heating value [93]. The corrosion problem is the main challenge of this method, according to using the alkali solution. So, new materials are also being developed to be used as an alternative diaphragm material.

\subsubsection{Proton Exchange Membrane Electrolyser}

To overcome the corrosion has happened from the alkaline electrolysers method, the solid polymer membrane has been investigated to use in the PEM fuel cells technology [107]. However, the deionized water with high purity has been required for the water electrolysis process [106]. The oxidation reaction of water is happened at the anode part generating oxygen, electrons, and protons. The electrons and protons are moved to the cathode side through the PEM. The hydrogen gas is generated at the cathode part after the porotons reduced. The PEM reactions are expressed as follows:

Anode reaction:

$$
2 \mathrm{H}_{2} \mathrm{O} \rightarrow \mathrm{O}_{2}+4 \mathrm{H}^{+}+4 \mathrm{e}^{-}
$$

Cathode reaction:

$$
4 \mathrm{H}^{+}+4 \mathrm{e}^{-} \rightarrow 2 \mathrm{H}_{2}
$$


The overall equation is same as the alkaline electrolyser Equation (3). The PEM electrolyser system has been investigated that it can be used with the fluctuation power supply source, according to the portons transportation through the PEM membrane is so quickly [103]. The high manufacturing cost is the major challenge of the PEM systems.

\subsubsection{Solid Oxide Electrolyser}

The solid oxide electrolyser (SOE) operation temperature can be reached at $1000^{\circ} \mathrm{C}$ compared with the PEM electrolyser. Figure 3 is illustrated that these systems typically are used the thermal energy instead of a part of the electrical energy [108]. It was investigated that the electrolyser efficiency is increased by increasing high temperature [108] [109]. Therefore, compared to alkaline and PEM processes the SOE process has a higher efficiency. In the SOE system, hydrogen is generated at the cathode part and the oxide anions are passed to the anode where oxygen will form through the solid electrolyte [107]. The following reactions are taking place in an SOE:

At anode:

$$
\mathrm{O}^{2-} \rightarrow \frac{1}{2} \mathrm{O}_{2}+2 \mathrm{e}^{-}
$$

At cathode:

$$
2 \mathrm{H}_{2} \mathrm{O}+2 \mathrm{e}^{-} \rightarrow \mathrm{H}_{2}+\mathrm{O}^{2-}
$$

This method is also used in fuel cells as a solid oxidation electrolysis cells (SOEC).

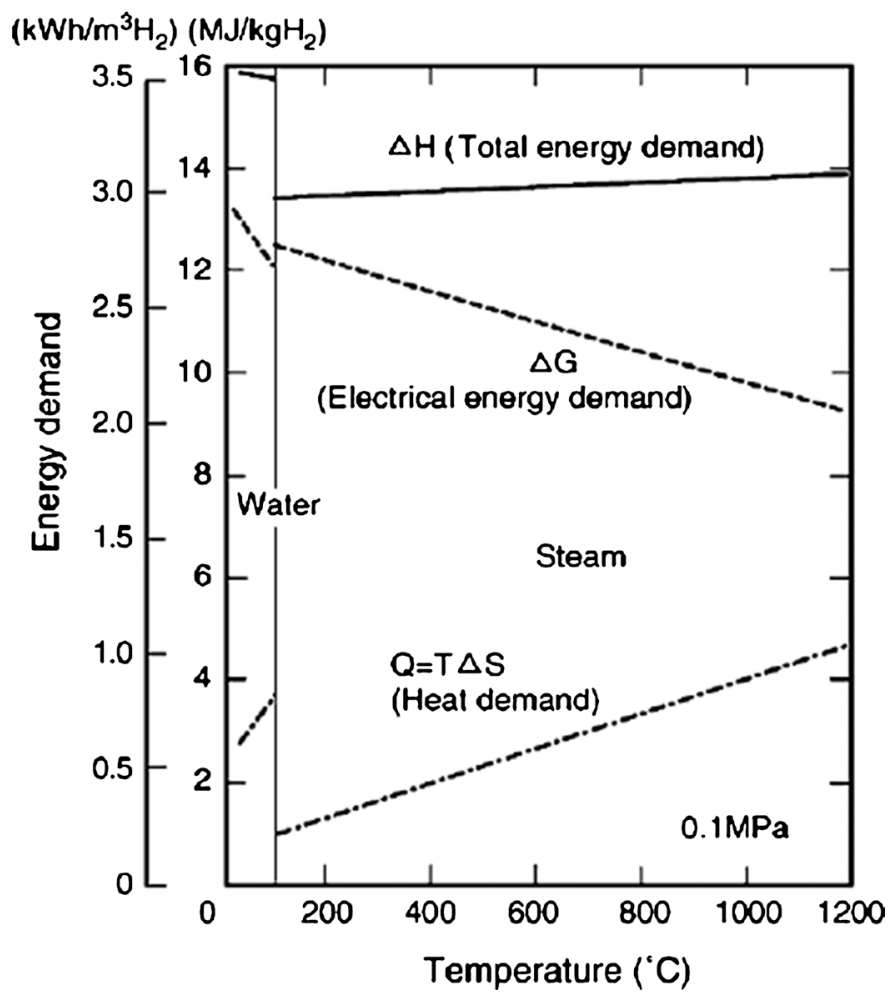

Figure 3. Energy demand for water and steam electrolysis [108]. 
SOEC systems are operated at a high temperature from nuclear reactors and can achieve efficiency up to $60 \%$ [102]-[115].

\subsection{Thermolysis \& Thermochemical Water Splitting}

\subsubsection{Thermolysis}

In the thermolysis process water is directly split using thermal energy as the energy input or it can be split indirectly using some other chemical materials [113]. The following is the thermolysis chemical reaction equation:

$$
\mathrm{H}_{2} \mathrm{O} \stackrel{\text { Heat }}{\longrightarrow} \mathrm{H}_{2}+\frac{1}{2} \mathrm{O}_{2}
$$

Thermolysis and thermochemical water decomposition methods can be seemed to be the same methods, regardless of the high temperature source. This means the thermochemical process deals with the chemical reactions and the heat transfer processes. It was investigated that if the temperature reached over $2000^{\circ} \mathrm{C}$, water is started to decompose without using other chemical materials [113]. It was presented that the thermolysis process is a direct thermal splitting of water at too high temperature [92]. This means that the material selection is very difficult to be suited with the high temperature. Also, it has been investigated that the main challenge of the thermolysis process is to develop an effective technique [92] [104] [116] [117].

\subsubsection{Thermochemical Water Splitting}

In the thermochemical water splitting process, it was combining the thermolysis water splitting process and the chemical reactions to reduce the water decomposition temperature to $900^{\circ} \mathrm{C}$ [104]. The hydrogen production using the thermochemical water splitting has been involved in different chemical reactions. Many studies have been developed to review the water splitting cycles [106] [118] [119]. Different thermochemical cycles have been studied [105] [120] such as copper-chlorine, Zinc-zinc oxide, nickel-manganese ferrite and the sulfur-iodine process. For example, the sulfur-iodine process as follows:

The first reaction is the sulfuric acid which is decomposed at $300^{\circ} \mathrm{C}$ to $500^{\circ} \mathrm{C}$ to release water without a catalyst,

$$
\mathrm{H}_{2} \mathrm{SO}_{4}(\mathrm{aq}) \stackrel{300^{\circ} \mathrm{C}-500^{\circ} \mathrm{C}}{\longrightarrow} \mathrm{H}_{2} \mathrm{O}(\mathrm{g})+\mathrm{SO}_{3}(\mathrm{~g})
$$

Then, $\mathrm{SO}_{3}$ is separated at $800^{\circ} \mathrm{C}$ to $900^{\circ} \mathrm{C}$ to release oxygen,

$$
\mathrm{SO}_{3}(\mathrm{~g}) \stackrel{800^{\circ} \mathrm{C}-900^{\circ} \mathrm{C}}{\longrightarrow} \mathrm{SO}_{2}(\mathrm{~g})+\frac{1}{2} \mathrm{O}_{2}
$$

The next reaction is done at low temperature to produce the sulfuric acid,

$$
\mathrm{SO}_{2}(\mathrm{~g})+\mathrm{I}_{2}(\mathrm{~g})+2 \mathrm{H}_{2} \mathrm{O}(\mathrm{l}) \rightarrow 2 \mathrm{HI}(\mathrm{g})+\mathrm{H}_{2} \mathrm{SO}_{4}(\mathrm{aq})
$$

Finally, hydrogen is produced from iodine decomposition within a temperature range of $425^{\circ} \mathrm{C}$ to $450^{\circ} \mathrm{C}$,

$$
2 \mathrm{HI}(\mathrm{g}) \stackrel{425^{\circ} \mathrm{C}-450^{\circ} \mathrm{C}}{\longrightarrow} \mathrm{H}_{2}(\mathrm{~g})+\mathrm{I}_{2}(\mathrm{~g})
$$

The challenge is faced this technology, the efficiency has to be increased by 
making scaling up [121].

\subsection{Photonic}

Hydrogen is produced from the photonic process by using the photon energy. It can be divided into two methods the photocatalytic and the photoelectrolysis water splitting (photoelectrochemical water splitting).

\subsubsection{Photocatalytic Water Splitting}

The hydrogen production by the Photocatalytic water splitting process is a direct method to produce hydrogen from water using the ordinary light. The low efficiency has been achieved by the photocatalytic method [122]. The main reactions of this process are as follows [123]:

$$
\begin{array}{cc}
\text { Photo-reduction } & 2 \mathrm{H}_{2} \mathrm{O}+2 \mathrm{e}^{-} \stackrel{h v}{\longrightarrow} \mathrm{H}_{2}+2 \mathrm{OH}^{-} \\
\text {Photo-oxidation } & 2 \mathrm{H}_{2} \mathrm{O} \stackrel{h v}{\longrightarrow} 4 \mathrm{H}^{+}+4 \mathrm{e}^{-}+\mathrm{O}_{2}(\mathrm{~g})
\end{array}
$$

The titanium oxide $\left(\mathrm{TiO}_{2}\right)$ is used in the photolysis reactions. Different researches are interested in photocatalyst development [124]-[128].

\subsubsection{Photoelectrolysis}

Photoelectrolysis has directly decomposed water into hydrogen and oxygen by using the sunlight. The photoelectrolysis systems are the same as the photovoltaic systems, both technologies are used the semiconductor materials. In photovoltaic, p-type and n-type semiconductor materials are used [94]. The electric current is created, due to the forced movement in the opposite direction of the electron and hole [93] [129]. In photoelectrolysis process instead of generating the electric current water is decomposed into hydrogen and oxygen [93] [94] [100] [129]. The reaction of photoelectrolysis is illustrated as follows [123]:

$$
\mathrm{H}_{2} \mathrm{O} \stackrel{h v}{\longrightarrow} \mathrm{H}_{2}(\mathrm{~g})+\frac{1}{2} \mathrm{O}_{2}(\mathrm{~g})
$$

Different photo electrodes materials such as $\mathrm{WO}_{3}, \mathrm{Fe}_{2} \mathrm{O}_{3}$, and $\mathrm{TiO}_{2}$ have been investigated to use in photoelectrolysis method as a thin-film [114] [130] [131]. The photoelectrolysis systems performance is mainly based on the utilized materials of the photoelectrodes and the semiconductor. The hydrogen production efficiency has been studied by [93] [94] [100] [129]. It has been investigated that the achieved efficiency of a single band gap is $18.3 \%$, dual-band gap systems over $30 \%$ conversions [132].

\subsection{Biomass}

Biomass energy is used to generate hydrogen fuel as a renewable energy source. Biomass energy sources such as agricultural wastes, animal wastes, municipal solid wastes...etc. have been investigated [133]-[151]. A comparison between the fossil fuels and biomass energy is illustrated in Table 3. The biomass technologies for hydrogen production can be divided into the gasification, pyrolysis which it was followed by the reforming process [149]. The basic reactions of 
biomass gasification process are listed in Table 4. The hydrogen production yield of the biomass process has been affected with the biomass characteristics and compositions are affected with a number of process variables such as temperature, heating rate, moisture content, particle size, reactor system...etc. [152] [153].

\subsubsection{Biomass Gasification Process}

The Gasification process can be commonly used in the biomass and coal gasification processes. It is commercially used in many processes and it has been based upon the partial oxidation process of the materials to get the mixture of hydrogen, carbon monoxide, methane...etc. [145]. Since the moisture has to be vaporized, the thermal efficiency of the gasification process is typically low [133]. Different studies have been presented for the gasification process with and without a catalyst using the fixed bed and the fluidized bed reactor [139] [144] [148] [155]. The recorded performance of the fluidized bed reactors is higher than the fixed bed type reactors [144]. Syngas is produced from steam reforming process when steam or oxygen is added to the gasification process, which it can be utilized for hydrogen production in the water gas shift (WGS) or the Fischer-Tropsch reactor [144] [149]. Biomass is dried by using superheated steam at $900^{\circ} \mathrm{C}$. The high hydrogen production yields can be achieved from the dried

Table 3. Advantages and disadvantages of hydrogen production from biomass [154].

\begin{tabular}{|c|c|}
\hline Advantages & Disadvantages \\
\hline 1) Mitigating $\mathrm{CO}_{2}$ emissions & 1) Seasonal availability and high handling costs \\
\hline $\begin{array}{l}\text { 2) Crop residues conversion increases the } \\
\text { value of agricultural output }\end{array}$ & 2) Non-total solid conversion and tars production \\
\hline $\begin{array}{l}\text { 3) Replacing fossil fuels with sustainable } \\
\text { biomass fuel }\end{array}$ & $\begin{array}{l}\text { 3) Fuel process limitations: corrosion, pressure, } \\
\text { resistance and hydrogen aging. }\end{array}$ \\
\hline $\begin{array}{l}\text { 4) Cost of getting rid of municipal solid } \\
\text { wastes }\end{array}$ & \\
\hline
\end{tabular}

Table 4. Basic reactions biomass gasification processes [152].

\begin{tabular}{cc}
\hline Reaction mode & Reaction equation \\
\hline Pyrolysis & $\mathrm{C}_{6} \mathrm{H}_{10} \mathrm{O}_{5} \rightarrow 5 \mathrm{CO}+5 \mathrm{H}_{2}+\mathrm{C}$ \\
$\mathrm{C}_{6} \mathrm{H}_{10} \mathrm{O}_{5} \rightarrow 5 \mathrm{CO}+3 \mathrm{H}_{2}+\mathrm{CH}_{4}$ \\
$\mathrm{C}_{6} \mathrm{H}_{10} \mathrm{O}_{5}+\frac{1}{2} \mathrm{O}_{2} \rightarrow 6 \mathrm{CO}+5 \mathrm{H}_{2}$ \\
$\mathrm{C}_{6} \mathrm{H}_{10} \mathrm{O}_{5}+\mathrm{O}_{2} \rightarrow 5 \mathrm{CO}+5 \mathrm{H}_{2}+\mathrm{CO}_{2}$ \\
$\mathrm{C}_{6} \mathrm{H}_{10} \mathrm{O}_{5}+2 \mathrm{O}_{2} \rightarrow 3 \mathrm{CO}+5 \mathrm{H}_{2}+3 \mathrm{CO}_{2}$ \\
\\
Partial oxidation & $\mathrm{C}_{6} \mathrm{H}_{10} \mathrm{O}_{5}+\mathrm{H}_{2} \mathrm{O} \rightarrow 6 \mathrm{CO}+6 \mathrm{H}_{2}$ \\
& $\mathrm{C}_{6} \mathrm{H}_{10} \mathrm{O}_{5}+3 \mathrm{H}_{2} \mathrm{O} \rightarrow 4 \mathrm{CO}+2 \mathrm{CO}_{2}+8 \mathrm{H}_{2}$ \\
& $\mathrm{C}_{6} \mathrm{H}_{10} \mathrm{O}_{5}+7 \mathrm{H}_{2} \mathrm{O} \rightarrow 6 \mathrm{CO}_{2}+12 \mathrm{H}_{2}$
\end{tabular}


biomass [133]. Based on the lower heating value, the achieved efficiencies of these reactors within range of $(35 \%$ - 50\%) [106] [118].

\subsubsection{Biological Hydrogen Production Process}

Bio-hydrogen researches are increased last several years, as attention to sustainable development and waste minimization [156]-[186]. This is another biomass method to produce hydrogen gas fuel using the biological technologies. It has been investigated that it can be utilized the anaerobic bacteria which it is grown in the dark fermentation bioreactors or can be used algae in the light in the photo fermentative process [184]. The main processes include the photolytic process to produce hydrogen from water using the green algae, the hydrogen production using the dark-fermentative process of anaerobic digestion, the two-stage dark/fermentative process, the photo-fermentative processes and the WGS method for hydrogen production [160] [165] [185]. The biological methods have been presented with a low environmental impact and high hydrogen production efficiency [78]. By using the anaerobic microorganisms the dark fermentation reaction is carried out to convert the carbohydrate to hydrogen and other final products [105] [186]. The following is the chemical reaction equation:

$$
\mathrm{C}_{6} \mathrm{H}_{12} \mathrm{O}_{6}+2 \mathrm{H}_{2} \mathrm{O} \rightarrow 2 \mathrm{CH}_{3} \mathrm{COOH}+2 \mathrm{CO}_{2}+4 \mathrm{H}_{2}
$$

The low hydrogen production capacity compared with the unit capital investment has been investigated that it was the major challenge of the dark fermentation method [187]. So, different extensive researches have been presented to get additional energy by adding and develop a new other two-stage system [188].

\section{Hydrocarbons Reforming Technology}

The hydrogen production from hydrocarbon fuels using reforming technology is presented. The Steam reforming process of hydrocarbons is considered the manufacturing dominating process of hydrogen production especially, for refineries. The hydrogen production technology using the hydrocarbon fuels can be divided into a steam reforming process, the partial oxidation process, and the auto-thermal reforming process (ATR). Table 5 is shown as a comparison

Table 5. Comparison of reforming technologies [189]-[191].

\begin{tabular}{ccc}
\hline Technology & Advantages & Disadvantages \\
\hline \multirow{2}{*}{ Steam reforming } & Most extensive industrial experience Oxygen not required & \\
& Lowest process temperature \\
Best $\mathrm{H}_{2} /$ CO ratio for $\mathrm{H}_{2}$ production & Highest air emission \\
Auto-thermal & Lower process temperature than POX & \\
& Low methane slip & Limited commercial experience \\
Partial oxidation & Decreased desulfurization requirement & Rer oxygen \\
& No catalyst required & Low $\mathrm{H}_{2} / \mathrm{CO}$ ratio \\
& Low methane slip & Very high processing temperatures
\end{tabular}


between the reforming processes [189] [190] [191].

In the steam reforming process, hydrogen gas, carbon monoxide and carbon dioxide gases are primarily composed in the gas flow stream; it has been investigated that by improving the operating conditions such as temperature, pressure, etc. in the fuel processing reactors will maximize the hydrogen production and minimize the carbon formation [192]-[199].

\subsection{Steam Reforming}

The steam reforming process is known as the hydrocarbons conversion with steam into hydrogen, carbon oxides, methane, and unconverted steam mixture. The typical feedstock ranges from natural gas and LPG to liquid fuels including naphtha and in some cases kerosene. In recent years steam reforming is also seen as an option for converting the primary feed into a gas suitable for a fuel cell. Different steam reforming reactors types have been used for specific applications [194]. The steam reforming process is considered the preferred hydrogen production process, the steam reforming process reactions are endothermic reactions, the operating temperature is typically lower than the POX and ATR methods while it can be produced a high H/CO ratio [192] [193] [194] [195] [196]. Table 6 shows the reactions of the steam reforming process.

It was investigated that in the fuel processing, moderate temperatures higher than $180^{\circ} \mathrm{C}$ is required [192]-[199]. The limitations of mass and heat transfer have been investigated to enable the kinetics of steam reforming by employing a micro-channel reactor [193] [200] [201] [202]. These systems have been utilized the noble Group VIII metals as alternatives catalysts such as Rh and Co-based catalyst [203] [204] [205]. It was showed a less coke formation and much higher activities compared with the nickel catalysts [200] [206] [207] [208]. The hydrogen production from methane using the steam reforming process is considered the common industrial method where it is given a high thermal efficiencies up to $85 \%$ according to the higher heating values [209]. The hydrogen fuel storage and transportation are very difficult due to the hydrogen fuel have a low energy per weight, additionally is a gaseous fuel. Thus, different on-site studies have been developed for steam reforming of hydrocarbons [210]-[216].

Table 6. The key reactions of steam reforming process [200].

\begin{tabular}{cccc}
\hline Reactions & Reaction description & \multicolumn{2}{c}{$\begin{array}{c}\text { Standard enthalpy of } \\
\text { reactions }\left[\mathrm{kJ} \cdot \mathrm{mol}^{-1}\right]\end{array}$} \\
\hline $\mathrm{CH}_{4}+\mathrm{H}_{2} \mathrm{O} \rightleftharpoons \mathrm{CO}+3 \mathrm{H}_{2}$ & Steam reforming & 206 & $\mathrm{R}(1)$ \\
$\mathrm{CO}+\mathrm{H}_{2} \mathrm{O} \rightleftharpoons \mathrm{CO}_{2}+\mathrm{H}_{2}$ & WGS & -41 & $\mathrm{R}(2)$ \\
$\mathrm{CH}_{4}+\mathrm{CO}_{2} \rightleftharpoons 2 \mathrm{CO}+2 \mathrm{H}_{2}$ & $\mathrm{CO}_{2}$ reforming & 247 & $\mathrm{R}(3)$ \\
$\mathrm{C}_{\mathrm{n}} \mathrm{H}_{\mathrm{m}}+\mathrm{nH}_{2} \mathrm{O} \rightleftharpoons \mathrm{nCO}+\left(\frac{\mathrm{m}}{2}+\mathrm{n}\right) \mathrm{H}_{2}$ & $\begin{array}{c}\text { Higher hydrocarbons steam } \\
\text { reforming }\end{array}$ & $1175^{*}$ & $\mathrm{R}(4)$ \\
\hline
\end{tabular}

*[Standard conditions at $P=1 \mathrm{~atm}, T=298 \mathrm{~K}$, for $\left.\mathrm{n}-\mathrm{C}_{7} \mathrm{H}_{16}\right]$. 


\subsection{Partial Oxidation}

The reaction of the partial oxidation (POX) method is an exothermic reaction and the reaction equation is presented in Equation (5). In the POX method the hydrogen produced is sent to the water-gas shift (WGS) reactor, and then is purified by using a suitable purification method. Compared with the steam reforming process, it has been investigated that the efficiency of the POX process is low; in addition, the operation cost is too high due to using high quantities of the pure oxygen [217]. The enthalpy of reactions for methane and isooctane are shown in Table 7.

$$
\mathrm{C}_{\mathrm{n}} \mathrm{H}_{\mathrm{m}}+\frac{\mathrm{n}}{2} \mathrm{O}_{2} \rightarrow \mathrm{nCO}+\frac{\mathrm{m}}{2} \mathrm{H}_{2}
$$

Example of the (POX) reaction:

$$
\mathrm{CH}_{3} \mathrm{OH}+\frac{1}{2} \mathrm{O}_{2} \rightarrow \mathrm{CO}_{2}+2 \mathrm{H}_{2} \quad \Delta H=-193.2\left[\mathrm{~kJ} \cdot \mathrm{mol}^{-1}\right]
$$

The hydrogen production from the partial oxidation of hydrocarbon using catalysts has been utilized in commercial applications and automobile fuel cells [218] [219] [220] [221] [222]. The effect of addition ruthenium ( $\mathrm{Ru})$ on the molybdenum (Mo) catalysts has been investigated for the production of syngas from methane $\left(\mathrm{CH}_{4}\right)$ via partial oxidation process [223]. The principles of (CPO) are illustrated in Figure 4.

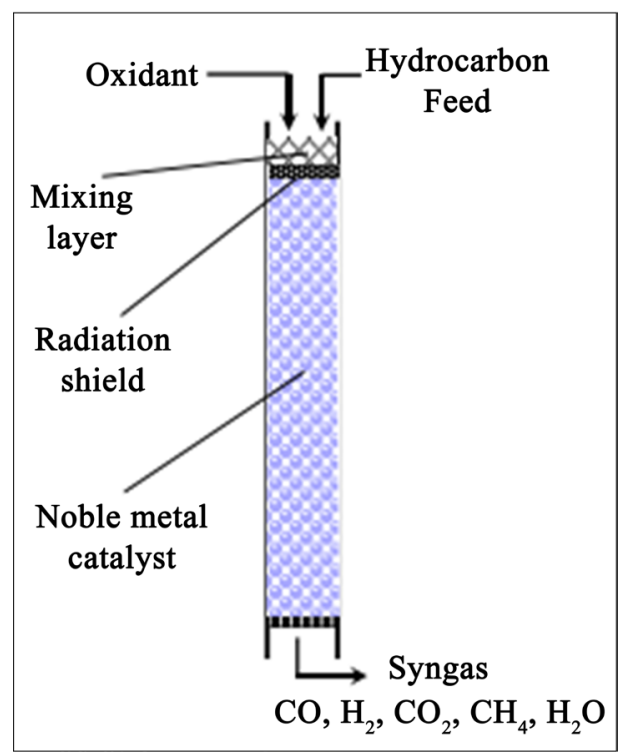

Figure 4. Catalytic partial oxidation principle [200].

Table 7. Standard enthalpies at (298 K, $1 \mathrm{~atm}), \Delta H$ in $[\mathrm{kJ} / \mathrm{mol}]$ [218].

\begin{tabular}{ccc}
\hline & Methane & Isooctane \\
\hline Partial oxidation & -36.1 & -675.8 \\
Steam reforming & 205.7 & 1258.8 \\
Dry CO$_{2}$ reforming & 246.9 & 1596.3 \\
\hline
\end{tabular}


Several studies have been carried to study $\mathrm{CPO}$ at different space velocities (low or moderate) and residence time (from $1 \mathrm{~s}$ or above) [224]-[229]. The importance of operating and design parameters has been investigated in another feature of the $\mathrm{CPO}$ process to prevent the explosions risk [230]. It is proved that the temperature is hard to be controlled due to the hot spot formation and the reactions nature is exothermic [219] [220] [221] [222]. The POX reactors efficiencies have been recorded based on the higher heating values for methane fuel is $60 \%-75 \%$ [209].

\subsection{Auto-Thermal}

Auto thermal reforming process has been done at low pressure compared with the POX reforming process. The heat required in the catalytic zone to drive the steam reforming reactions has been generated using the POX process [199] [224] [231] [232]. Figure 5 is illustrated the auto-thermal reactor components. The combustion chamber reaction equations are shown in Table 8.

Compared with the POX process, a significant advantage of the auto-thermal reaction process, it can be produced a large amount of hydrogen gas while the starting and stop are very rapidly. In the auto-thermal reaction process, it was considered that it must be controlled the temperature and preventing the coke formation by using the both of the steam to carbon ratio and the oxygen to fuel ratio [199] [224] [231].

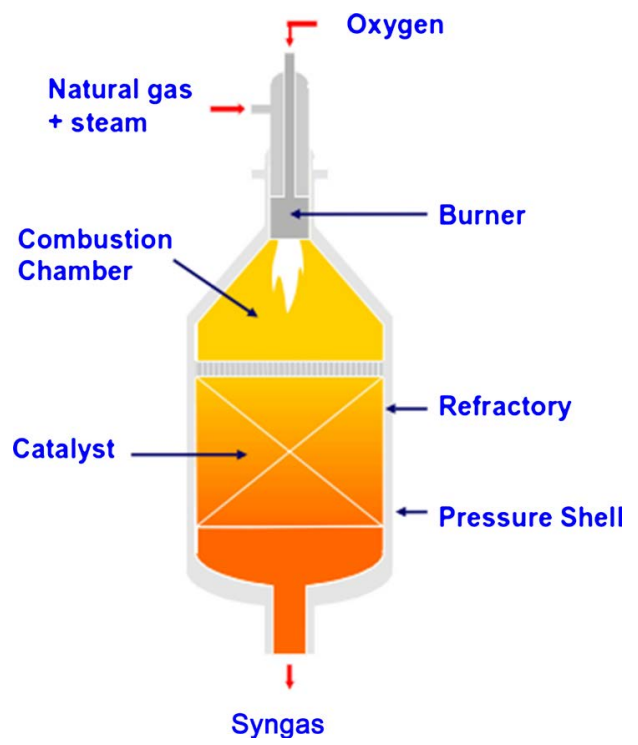

Figure 5. Illustration of an auto-thermal reactor [233].

Table 8. Simplified reactions in the combustion chamber of ATR [194]

\begin{tabular}{cccc}
\hline Reactions & Reaction description & Standard enthalpy of reactions $\Delta H\left[\mathrm{~kJ} \cdot \mathrm{mol}^{-1}\right]$ \\
\hline $\mathrm{CH}_{4}+3 / 2 \mathrm{O}_{2} \rightarrow \mathrm{CO}+2 \mathrm{H}_{2} \mathrm{O}$ & Combustion & -519 & $\mathrm{R}(7)$ \\
$\mathrm{CH}_{4}+\mathrm{H}_{2} \mathrm{O} \rightleftharpoons \mathrm{CO}+3 \mathrm{H}_{2}$ & Steam reforming & 206 & $\mathrm{R}(1)$ \\
$\mathrm{CO}+\mathrm{H}_{2} \mathrm{O} \rightleftharpoons \mathrm{CO}_{2}+\mathrm{H}_{2}$ & WGS & -41 & $\mathrm{R}(2)$ \\
\hline
\end{tabular}




\subsection{Gasification}

The gasification process is presented to be a sequence of a thermochemical transformations taking place at high temperatures between the organic part such as coal and the gasifying agent, like oxygen, steam, air, carbon dioxide [234] [235] [236]. The heat needed for the gasification process has been made by using the carbonaceous material (so it is called autothermic gasification) [234]. The water gas shift (WGS) process has been used to separate hydrogen and converting carbon monoxide into the carbon dioxide [104]. The gasification process heterogeneous and homogeneous reactions are summarized in Table 9 and Table 10 respectively.

The integrations of the coal gasification with other systems have been studied by different researches [239]-[249]. Thermodynamic evaluations using the first and second law of thermodynamics have been conducted on the integrated gasification systems in their analyses [242]-[250].

The hydrogen production from water decomposition using the Bryton cycle and a thermochemical copper-chlorine cycle have been investigated as a novel method to overcome the limitations of the hydrogen production from the coal composition and syngas hydrogen separation [251]. Koppers Totzek Coal gasification process can be produced pure hydrogen up to $97 \%$, it has been investigated that it has the ability in the near and midterm to keep the hydrogen production from the fossil fuel in practice from the solar thermal processes and carbon sequestration application [252]-[261].

Table 9. Major heterogeneous reactions taking place in the gasifier [234] [235] [236] [237].

\begin{tabular}{cccc}
\hline Reactions & Reaction description & \multicolumn{2}{c}{ Standard enthalpy of reactions $\left[\mathrm{kJ} / \mathrm{mol}^{-1}\right]$} \\
\hline $\mathrm{C}+\mathrm{CO}_{2} \rightleftharpoons 2 \mathrm{CO}$ & Reverse boudouard & 172.4 & $\mathrm{R}(8)$ \\
$2 \mathrm{H}_{2}+\mathrm{O}_{2} \rightleftharpoons 2 \mathrm{H}_{2} \mathrm{O}$ & & 131.3 & $\mathrm{R}(9)$ \\
$\mathrm{C}+2 \mathrm{H}_{2} \rightleftharpoons \mathrm{CH}_{4}$ & Methane formation & -74.9 & $\mathrm{R}(10)$ \\
$2 \mathrm{C}+\mathrm{O}_{2} \rightleftharpoons 2 \mathrm{CO}$ & Oxidation of CO & -221 & $\mathrm{R}(11)$ \\
$2 \mathrm{C}+\mathrm{O}_{2} \rightleftharpoons 2 \mathrm{CO}$ & Coke gasification & -393.6 & $\mathrm{R}(12)$
\end{tabular}

Table 10. Major homogenous reactions taking place in the gasifier [234] [235] [236] [238].

\begin{tabular}{cccc}
\hline Reactions & Reaction description & \multicolumn{2}{c}{ Standard enthalpy of reactions $\Delta H\left[\mathrm{~kJ} \cdot \mathrm{mol}^{-1}\right]$} \\
\hline $2 \mathrm{CO}+\mathrm{O}_{2} \rightleftharpoons \mathrm{CO}_{2}$ & Oxidation of $\mathrm{CO}$ & -566 & $\mathrm{R}(13)$ \\
$2 \mathrm{H}_{2}+\mathrm{O}_{2} \rightleftharpoons 2 \mathrm{H}_{2} \mathrm{O}$ & Oxidation of $\mathrm{H}_{2}$ & -483.6 & $\mathrm{R}(14)$ \\
$\mathrm{CO}+\mathrm{H}_{2} \mathrm{O} \rightleftharpoons \mathrm{CO}_{2}+\mathrm{H}_{2}$ & WGS & -41 & $\mathrm{R}(2)$ \\
$\mathrm{CO}+3 \mathrm{H}_{2} \rightleftharpoons \mathrm{CH}_{4}+\mathrm{H}_{2} \mathrm{O}$ & Methanation/hydrogenation & -206 & $\mathrm{R}(15)$ \\
$\mathrm{CH}_{4}+2 \mathrm{O}_{2} \rightarrow \mathrm{CO}_{2}+2 \mathrm{H}_{2} \mathrm{O}$ & Combustion & -802.6 & R(16) \\
\hline
\end{tabular}




\subsection{Pyrolysis}

The Pyrolysis process "can be defined as the decomposition of organic substances by heat" [262]. These decomposition reactions have been performed at $350^{\circ} \mathrm{C}$ to $400^{\circ} \mathrm{C}$ depending on the coal properties [263]. The other hydrocarbons thermal decomposition have been occurred at high temperatures such as methane thermal decomposition temperature is at $1400^{\circ} \mathrm{C}$ or higher. Significantly, the temperature of the pyrolysis process can be reduced by using the transition metal catalyst like ( $\mathrm{Ni}, \mathrm{Fe}, \mathrm{Co})$. It has been investigated that the pyrolysis process can be used the organic material [148] [264] [265] [266], additionally, it can be used for the hydrocarbons production, carbon nanotubes and spheres [148] [266]-[278].

The chemical reaction of the pyrolysis process can be generally expressed as follows [269]:

$$
\mathrm{C}_{\mathrm{n}} \mathrm{H}_{\mathrm{m}} \rightarrow \mathrm{nC}+\frac{1}{2} \mathrm{mH}_{2}
$$

The chemical decomposition equation of hydrocarbons using the pyrolysis process, it is showed that water and air aren't used. Consequently, carbon oxides don't appear in the reaction by-products. It was presented that the pyrolysis process has the flexibility to use any organic fuel, in addition to its compactness and the process by-product is carbon-free [152] [265] [266] [269]. Although the pyrolysis process advantages, there is a major potential fouling problem by the carbon formed and it can be reduced by using appropriate reactor design [152].

\section{Hydrocarbons Reforming Assisted by Using Plasma Technology}

Plasma "is known as the fourth state of the material" and it can be defined as an ionized gas. This technology has the challenge to produce hydrogen with the best energetic efficiency. The plasma technology can be classified into thermal and non-thermal plasma (non-equilibrium plasma) based on the energy level (temperature, plasma state, and electronic density). The electrically heated furnaces, combustion, flames, electric discharges, and shocks have been considered the plasma different generated methods [270]. Table 11 is shown the different plasma systems classifications and properties. The gas components temperature is the major difference between thermal plasma and no-thermal plasma technology [271] [272]. The high energetic densities can be released from the plasma process, so, the hydrogen production from hydrocarbons reforming applications using plasma with and without catalyst case studies have been discussed, in addition, the hydrogen production from ammonia decomposition using non-thermal plasma reactor. The plasma torch (DC) direct current has been used in the first plasma-assisted reformers which it was thermal ones. A comparison between new and old plasmatron for methane and diesel fuels of $\mathrm{H}_{2}$ yield for both kinds It has been shown in Figure 6 \& Figure 7 respectively [273]. These figures are illustrated that the non-thermal plasma systems have a low 
energy consumption compared with the thermal plasma systems. We will briefly describe thermal and non-thermal plasma methods.

\subsection{Thermal Plasma Technology}

Thermal plasma can be applied to different applications which required high temperature such as vehicles ignition systems, lighting applications, gasification

Table 11. Classification and properties of various plasma [272].

\begin{tabular}{|c|c|c|c|c|c|c|}
\hline Properties & Thermal Plasma & \multicolumn{5}{|c|}{ Non-thermal Plasma (Non equilibrium plasma) } \\
\hline Temperature & $\mathrm{Te} \approx \mathrm{Ti} \approx \mathrm{Tg} \leq 2 \times 10^{4} \mathrm{~K}$ & \multicolumn{5}{|c|}{$\mathrm{Te} \gg \mathrm{Ti} \approx \mathrm{Tg} \leq 300 \ldots . .103 \mathrm{~K}$} \\
\hline Density & $\geq 1020 \mathrm{~m}^{-3}$ & \multicolumn{5}{|c|}{$1010 \mathrm{~m}^{-3}$} \\
\hline Classification: & Thermal arc plasma & $\begin{array}{l}\text { Gliding arc } \\
\text { discharge }\end{array}$ & $\begin{array}{c}\text { Dielectric barrier } \\
\text { discharge }\end{array}$ & $\begin{array}{c}\text { Corona } \\
\text { discharge }\end{array}$ & Glow discharge & $\begin{array}{c}\text { Atmospheric } \\
\text { pressure plasma } \\
\text { jet }\end{array}$ \\
\hline Excitation & $\mathrm{DC}$ & $\mathrm{DC} / \mathrm{AC}$ & $\mathrm{AC} / \mathrm{RF}$ & Pulsed DC & $\mathrm{DC} / \mathrm{AC}$ & $\mathrm{RF}(13.5 \mathrm{MHz})$ \\
\hline Pressure, bar & $0.1-100$ & $\sim 1$ & $\sim 1-3$ & $\sim 1$ & $<10$ mbar & $\sim 1$ \\
\hline Electron energies, eV & $1-10$ & $1.4-2.1$ & $1.0-30$ & $\sim 5$ & $2.0-8.0$ & \\
\hline Electron density, & $1015-1019$ & $>1013$ & $1012-1015$ & $109-1013$ & $109-1012$ & $1011-1012$ \\
\hline \multicolumn{7}{|l|}{$\mathrm{cm}^{-3}$} \\
\hline Breakdown voltage, & $10-100$ & $0.5-4.0$ & $5.0-25$ & \multicolumn{2}{|c|}{$10.0-50.0$} & $0.05-0.2$ \\
\hline \multicolumn{7}{|l|}{$\mathrm{kV}$} \\
\hline Current, A & $30-30,000$ & $10-1-50$ & $1.0-50$ & $<10-5$ & $10-5-1$ & \\
\hline Tmac, $\mathrm{K}$ & $5 \times 10^{3}-10^{4}$ & $1000-3000$ & $\sim 300$ & $\sim 400$ & $\sim 700$ & $\sim 400$ \\
\hline Carrier gas & air, $\mathrm{N}_{2}, \mathrm{O}_{2}$, etc. & $\mathrm{N}_{2}, \mathrm{O}_{2}, \mathrm{Ar}$ & $\mathrm{N}_{2}, \mathrm{O}_{2}$, rare gas & $\mathrm{N}_{2}, \mathrm{O}_{2}, \mathrm{Ar}$ & $\mathrm{N}_{2}, \mathrm{O}_{2}, \mathrm{Ar}$ & $\mathrm{He}, \mathrm{Ar}$ \\
\hline
\end{tabular}

"RF inductivity coupled discharge. Te, $\mathrm{Ti}$ and $\mathrm{Tg}$ refer to the temperature of electrons, ions, and neutral species (atoms, molecules, radicals and excited species) respectively.

$\mathrm{H}_{2}$ Yield vs Energy Consumption. $\mathrm{CH}_{4}$

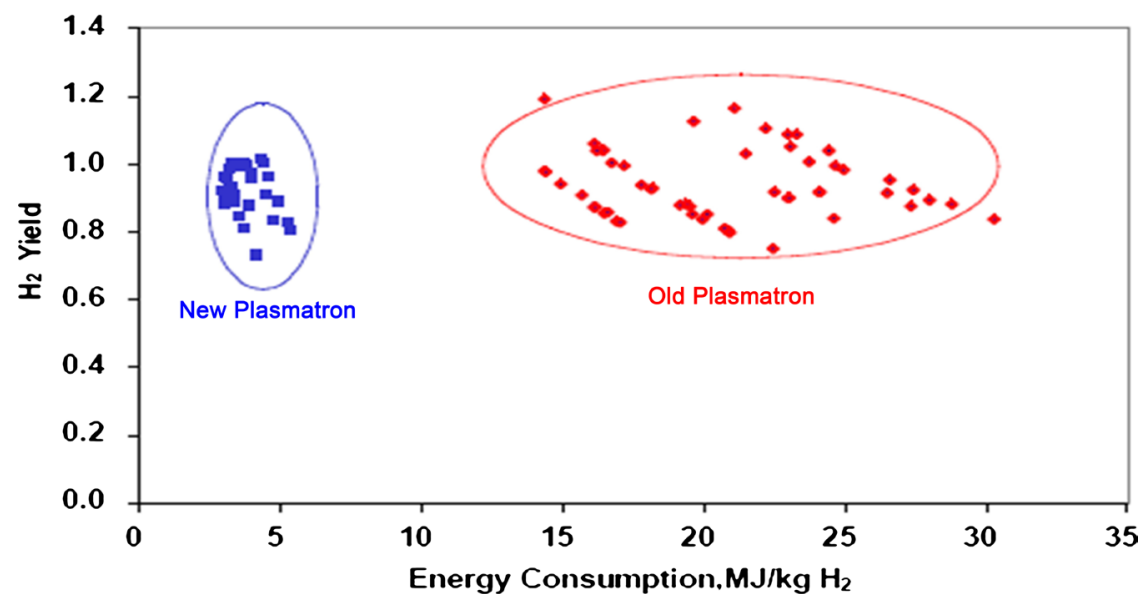

Figure 6. Comparisons of energy costs for non-thermal and thermal plasmas reforming of Methane [273]. 


\section{$\mathrm{H}_{2}$ Yield vs Energy Consumption for Diesel Reforming}

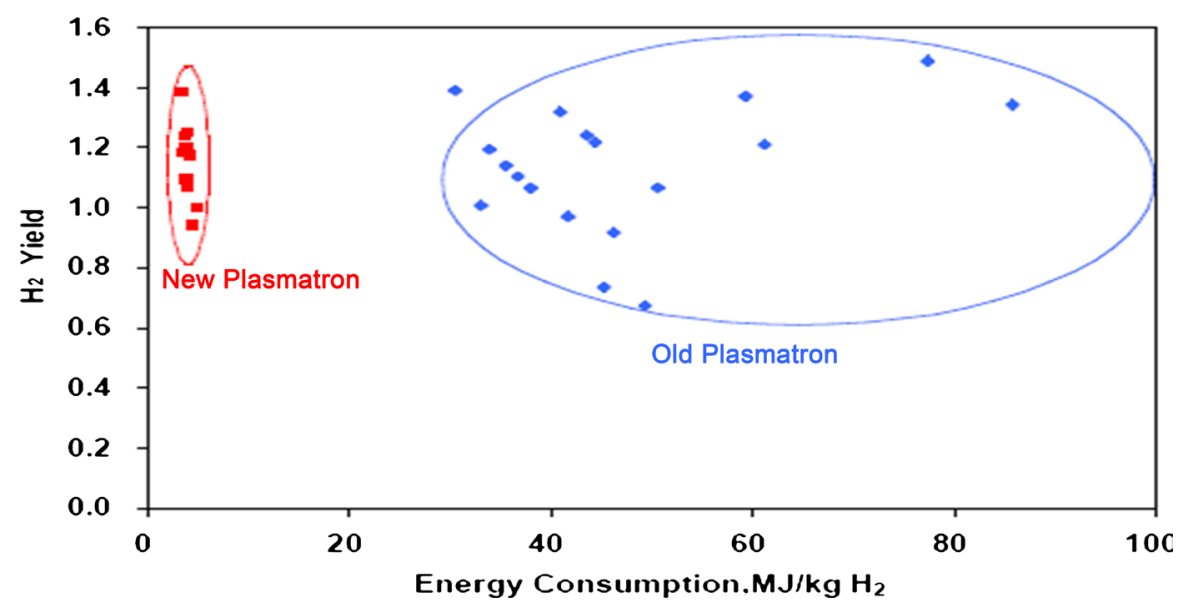

Figure 7. Comparisons of energy costs for non-thermal and thermal plasmas reforming of diesel [273].

of solid fuels. Due to the thermal plasma technology high temperature, it has been limited for some liquid fuels reforming due to the electrode erosion. It has been characterized that the thermal plasma technology has a highly degree of dissociation and a substantial ionization degree [274]. Thermal plasma has an important range of application that includes synthesis of Nanopowders, destruction, and treatment of hazardous waste, metallurgy application (smelting operations and re-melting application in large furnaces) surface modification and coating, chemical synthesis [275]. Thermal degradation (gasification) of the organic carbon-based materials have been carried out at a temperatures range of $400^{\circ} \mathrm{C}$ to $1500^{\circ} \mathrm{C}$ [276]. It has been investigated that the thermal plasma technology can be used in waste treatment such as healthcare wastes, steel making waste....etc. [277]-[283]. The economic studies have been presented that the insufficient control is the main disadvantages of the waste treatment using thermal plasma method [284]. In addition, the reforming process for alcohols using thermal plasma technology has been limited [285].

A high electric discharge over $1 \mathrm{~kW}$ has been used in hydrocarbons reforming process by using thermal plasma technology; also, the cooling power has been required to decrease the electrode temperature to stop the vaporization of metal [274] [276] [287]. Figure 8 is shown the methane conversion with the input power to the thermal plasma reactor [274]. The thermal plasma is usually used high temperature, it will increase the energy cost, in addition to unwanted coking and soot. Catalysts have been utilized to reduce the reaction temperature, additionally; the required activation energy of fuel conversion is reduced.

\subsection{Non-Thermal Plasma Technology}

The non-thermal plasma method is more suitable for the hydrocarbons reforming and producing syngas. According to the non-thermal plasma method, the chemical reactions have been happened at low input power and at low temperatures 
[288]. In non-thermal plasma technology, the electron temperature can be reached $(10,000$ to $100,000 \mathrm{~K})$ and at the same time, the gas temperature is at the room temperature [289] [290]. Different reactors have been used for applying the different plasma technologies like the dielectric barrier discharge (DBD) reactors [290] [291], gliding arc discharge [285] [292] [293] [294] [295], corona [290] and microwave [296] [297] [298]. It has been utilized in hydrocarbons reforming such as diesel, methane, and biofuels [274] [291] [299]-[305].

The non-thermal plasma process main effect parameter is the electron temperatures which temperatures are raised higher than $5000 \mathrm{~K}$ [285] [286] [306]. Dielectric barrier discharge (DBD), gliding arc discharge plasma, corona discharge and microwave plasma is the non-thermal plasma types [285] [306]-[315]. In the first three types, the dynamic discharge is used to create plasma. The main different parameters between non-thermal plasma types are the controlling method of the current and discharging power, additionally, reactor design, flow rate and the power supplies which have been described [285]. The gliding arc discharge which has a good selectivity and high production rate will briefly describe in this article. Table 12 differentiates the efficiencies of the non-thermal plasma methods and it is shown that the gliding arc discharge has the highest non-thermal plasma efficiency. Figure 9 illustrates the gliding arc discharge which has two

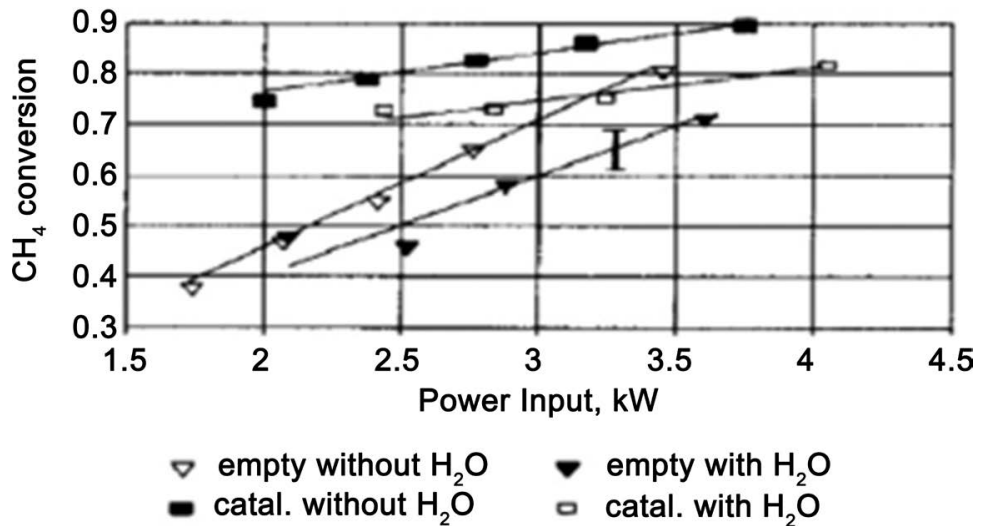

"Empty reactor: plasmatron air $=0.4 \mathrm{~g} / \mathrm{s}$, fuel $=0.27 \mathrm{~g} / \mathrm{s}$, additional air $=0.7 \mathrm{~g} / \mathrm{s}$. In the case of water addition, $0.2-0.5 \mathrm{~g} / \mathrm{s} \mathrm{H}_{2} \mathrm{O}$ added. Catalytic case: plasmatron air $=0.35 \mathrm{~g} / \mathrm{s}$, fuel $=0.25-0.5 \mathrm{~g} / \mathrm{s}$, additional air $=$ $0.5-1 \mathrm{~g} / \mathrm{s}$. In the case of water addition, $0.5-0.8 \mathrm{~g} / \mathrm{s}$ water".

Figure 8. Methane conversion as a function of power input [274].

Table 12. Plasma reformer efficiencies [285].

\begin{tabular}{|c|c|c|c|c|c|c|c|c|c|c|}
\hline \multirow{2}{*}{ Technology } & \multirow{2}{*}{ Fuel } & \multicolumn{3}{|c|}{ Experimental conditions } & \multicolumn{4}{|c|}{ Products (dry vol. \%) } & \multirow{2}{*}{$\begin{array}{c}\text { Reformate } \\
\text { Temperature }[\mathrm{K}]\end{array}$} & \multirow{2}{*}{ Efficiency } \\
\hline & & Chemical Reaction & Air Ratio & $\mathrm{S} / \mathrm{C}$ & $\mathrm{H}_{2}$ & $\mathrm{CO}$ & $\mathrm{CO}_{2}$ & $\mathrm{CH}_{4}$ & & \\
\hline Gliding arc non-thermal & Diesel & ATR & 0.4 & 1.8 & 23 & 17 & 6.2 & 1.2 & $1000-1300$ & 85 \\
\hline Corona discharge + catalyst & Iso-octane & ATR & 0.28 & 1 & 46 & 16 & 16 & - & $900-1100$ & 55 \\
\hline Gliding arc thermal & Iso-octane & POX & 0.25 & - & 22 & 15 & 2 & 3 & 1200 & 9 \\
\hline Gliding arc thermal & Diesel & POX & 0.25 & - & 23.5 & 23 & 0.1 & 0.03 & 1200 & 9 \\
\hline Microwave & Hexane & SR & - & 2 & 66 & 25 & 4 & - & $?$ & ? \\
\hline
\end{tabular}



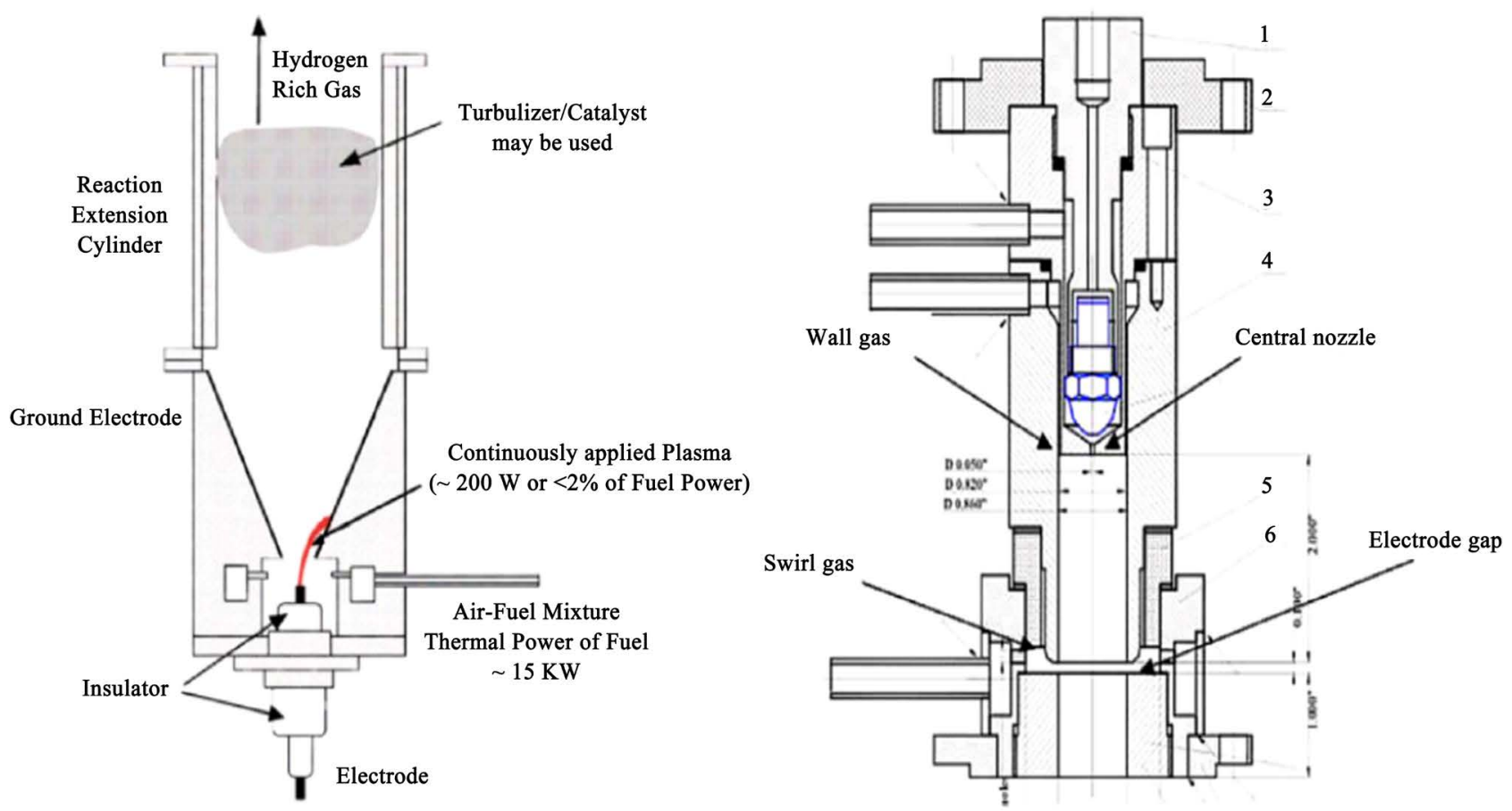

Figure 9. Scheme of Gliding Arc reactor [312].

electrodes and a simple feeding electrical system [312]. The arc is formed while the gas enters the reactor and the high voltage is applied. The arc is pushed down by the gas along the reactor length and is turned off at the reactor end, and then the new arc is formed again at the reactor gas inlet. It has been investigated that the gliding arc discharge method can be used the DC or AC currents, in addition, a simple feeding power supply system compared with the other non-thermal plasma systems [285].

\section{Hydrogen Production Using Ammonia $\left[\mathrm{NH}_{3}\right]$ by Using Plasma Decomposition}

All efforts are made by researchers to provide the World with hydrogen fuel. In a different way, a new hydrogen production method from ammonia decomposition using plasma technology has been investigated. This plasma technology type has the ability to produce a $99.999 \%$ of pure hydrogen gas at normal temperature, atmospheric pressure and without using a catalyst. Prof. Shinji Kambara of Gifu University, Japan, Division of Environmental and Renewable Energy Systems is collaborated with Sawafuji Electric Co., Ltd and has been developed a novel hydrogen production method using ammonia decomposition by using a DBD plasma reactor. The newly developed prototype can be applied to fuel cell. Also, it has Low-cost, low environmental impact and highly efficient hydrogen production equipment based on ammonia gas. The flowing ammonia gas is decomposed into hydrogen and diatomic nitrogen through the plasma field as follows:

$$
\mathrm{NH}_{3}+\mathrm{e}^{-} \rightarrow \frac{1}{2} \mathrm{~N}_{2}+\frac{3}{2} \mathrm{H}_{2}
$$


This study confirmed that the power generation by using the hydrogen obtained from the installation as a fuel cell. Hydrogen production equipment that can store and supply hydrogen. It is expected to spread for industrial and domestic fuel.

\section{Ammonia decomposition case studies}

Hydrogen production from $\left(\mathrm{NH}_{3}\right)$ using high electron energy obtained by atmospheric pressure plasma is a promising method for producing purified hydrogen from ammonia. A comparison between the two cases of ammonia decompositions has been investigated. Also, the influence of applied voltage, $\mathrm{NH}_{3}$ concentration and $\mathrm{NH}_{3}$ gas residence time on $\mathrm{H}_{2}$ yield has been discussed. According to their study, the hydrogen yield increases as higher applied voltage, longer residence time and lower $\mathrm{NH}_{3}$ concentration [316]. A plasma membrane reactor has been designed as a novel plasma reactor combining $\mathrm{H}_{2}$ separation membrane [317].

\section{1. $\left[\mathrm{NH}_{3}\right]$ Decomposition Using a Cylindrical Plasma Reactor without Catalytic Materials}

The hydrogen production method from $\mathrm{NH}_{3}$ at atmospheric pressure plasma membrane reactor (PMR) by dielectric barrier discharge has been studied. Figure 10 shows the plasma reactor with the palladium alloy membrane, it is utilized to improve the efficiency of hydrogen production from ammonia decomposition [318]. The PMR has been composed of a quartz glass tube and a palladium separation membrane which has a thickness of $20 \mu \mathrm{m}$ thickness and welded inside a thin punched metal (SUS 304). The gap length was $1.5 \mathrm{~mm}$. The gap volume is $51.6 \mathrm{~cm}^{3}$, respectively. Figure 11 \& Figure 12 showed the PMR before and after firing plasma respectively.

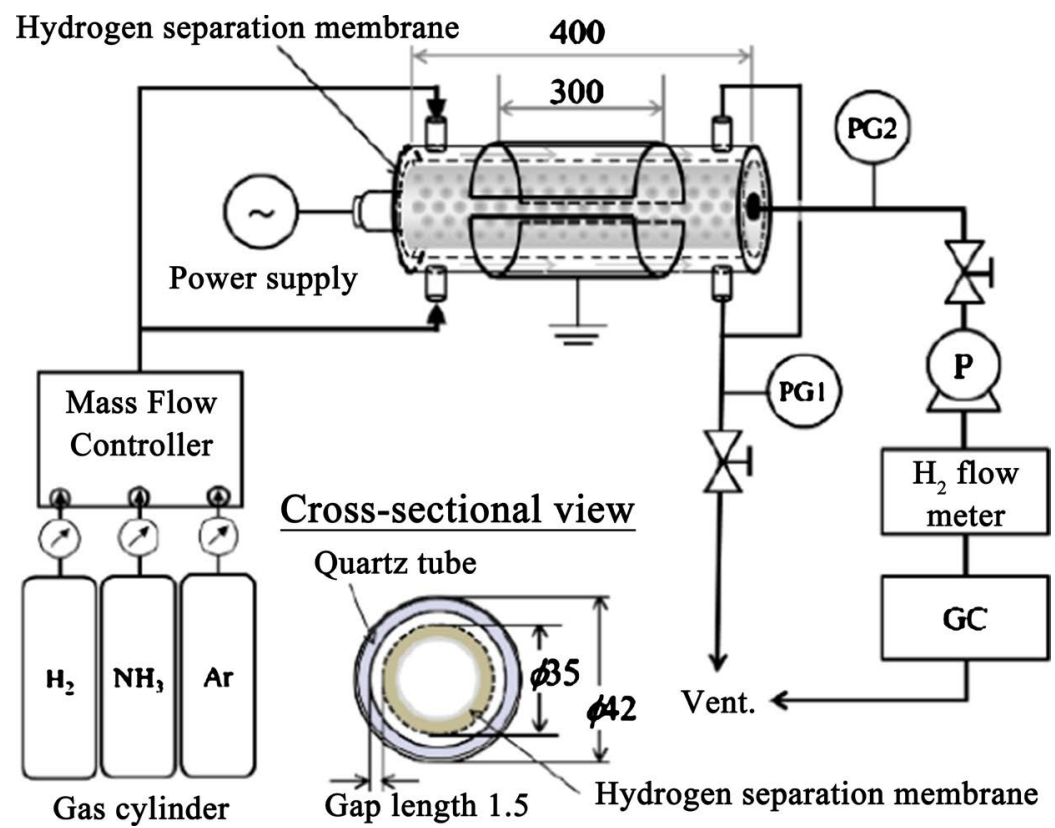

Figure 10. Experimental setup for hydrogen production by PMR [318]. 


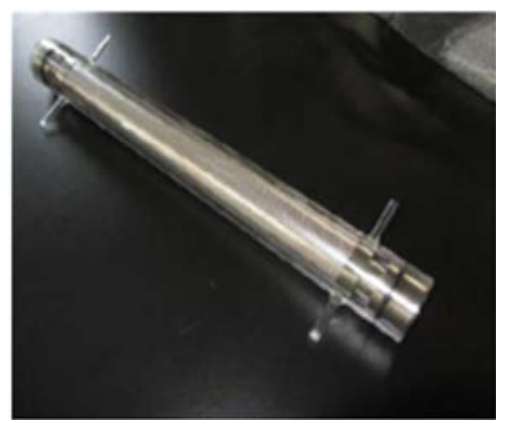

Figure 11. PMR before firing plasma.

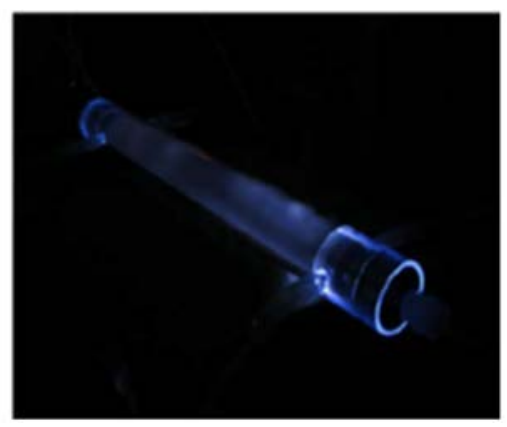

Figure 12. PMR after firing plasma.

\section{Performance analysis}

Firstly, the PMR has been examined using the pure hydrogen gas to check the hydrogen separation from the reactor. The hydrogen separation characteristics of the PMR via the induced pressure have been investigated [318]. It is known that the hydrogen permeation through the palladium membrane has been affected by the partial pressure [319].

The first attempt of hydrogen production using a cylindrical plasma reactor (PR) has been presented that the hydrogen produced from ammonia flow rate higher than $60 \mathrm{~L} / \mathrm{h}$ remained constant [318]. Figure 13 shows the hydrogen production flow rates with the increase in the ammonia gas flow rate. The maximum flow rate of the hydrogen production was $21.0 \mathrm{~L} / \mathrm{h}$ at a flow rate 30 $\mathrm{L} / \mathrm{h}$ of the ammonia gas $\left(\mathrm{NH}_{3}\right)$. The energy efficiency was $4.42 \mathrm{molH}_{2} / \mathrm{kWh}$ which is based on the power supply to the plasma reactor.

\subsection{Ammonia Decomposition Using PMR Using Catalytic Materials}

In this case study, the catalyst has been used as the PMR reactor is continuously developed to produce hydrogen from ammonia gas with a high purity [320]. Figure 14 is presented the experiment layout of hydrogen production using a catalyst. The catalytic reactor consisted of a stainless tube ( $\varphi 18 \mathrm{~mm}$, SUS316), cylindrical ceramic fiber heater and inside the catalytic reactor, $10 \% \mathrm{Ni} / \mathrm{Al}_{2} \mathrm{O}_{3}$ was packed as a pyrolysis catalyst for $\mathrm{NH}_{3}$.

\section{Performance analysis}

The development of a system for producing hydrogen from ammonia has been developed by combining a catalytic reaction and a plasma membrane reactor 


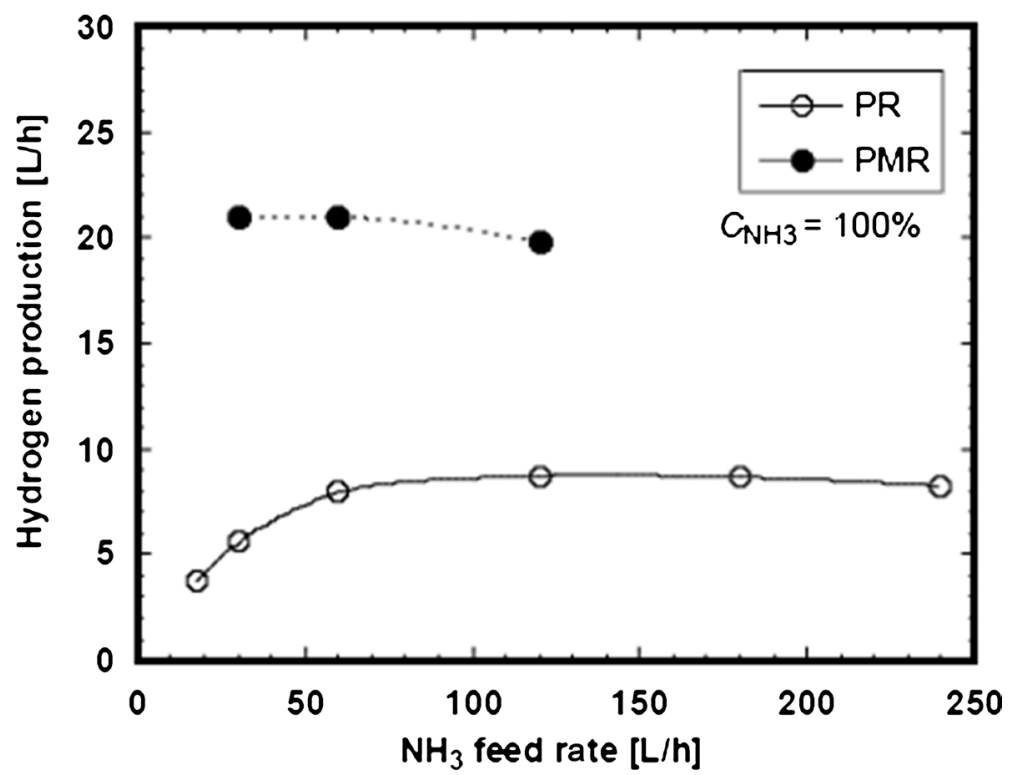

Figure 13. Hydrogen production performance of the PMR and PR [318].

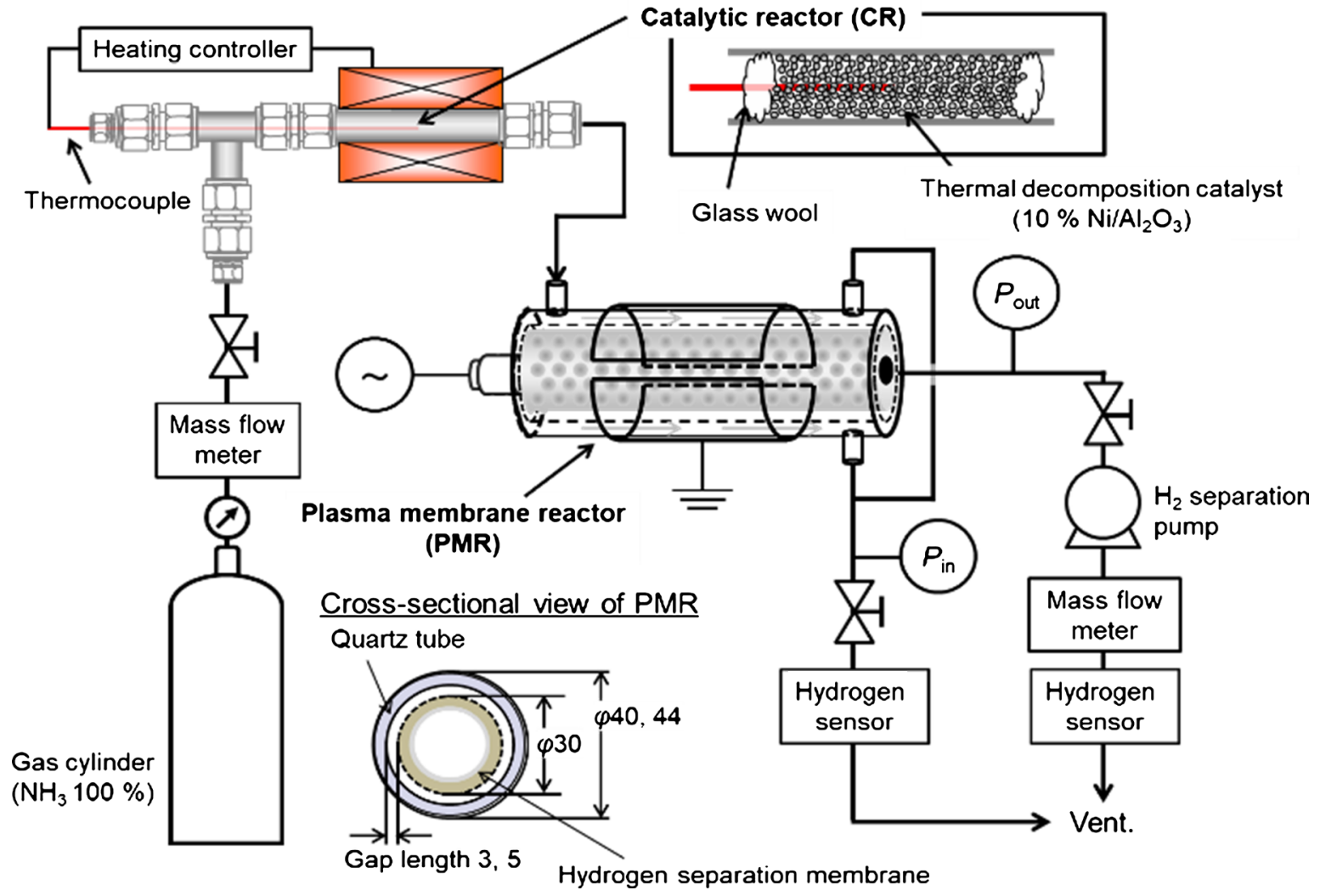

Figure 14. Experimental setup for hydrogen production using catalytic PMR [320].

[320]. The gap length between the glass quartz tube and the hydrogen separation membrane effect has been studied. Figure 15 is shown the gap length effect on the flow rate of the produced hydrogen gas.

The maximum flow rate of hydrogen production was $120 \mathrm{~L} / \mathrm{h}$ at ammonia gas flow rate $5.0 \mathrm{~L} / \mathrm{min}$ and a supplied voltage $110 \mathrm{~V}$. The catalytic reactor with $10 \%$ 


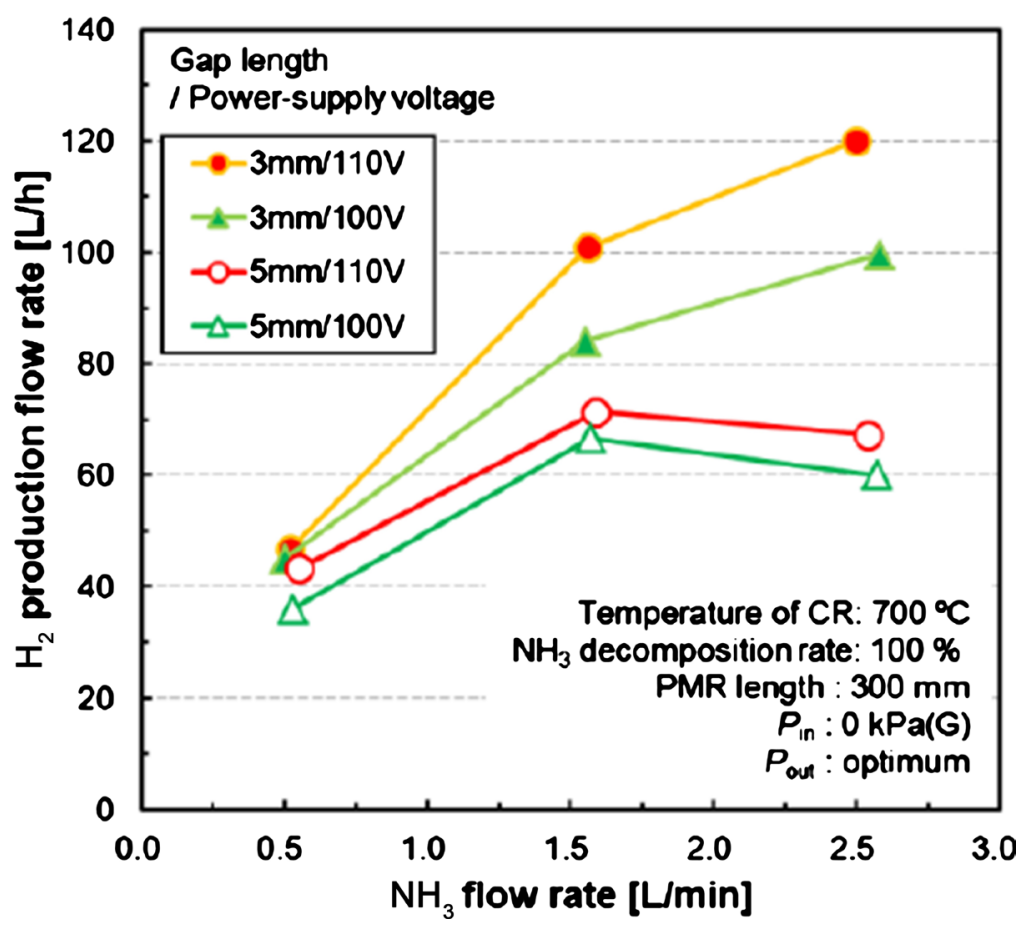

Figure 15. The effect of gap length inside the PMR on hydrogen purification [320].

$\mathrm{Ni} / \mathrm{Al}_{2} \mathrm{O}_{3}$, ammonia $\left(\mathrm{NH}_{3}\right)$ has been completely decomposed at $700^{\circ} \mathrm{C}$. The maximum energy efficiency is obtained from the developed hydrogen production system was $28.3 \%$. A comparison between the hydrogen production from the non-catalytic plasma reactor and the catalytic plasma reactor has been presented in Figure 16. It was clear that the ammonia decomposition using catalytic material $\left(10 \% \mathrm{Ni} / \mathrm{Al}_{2} \mathrm{O}_{3}\right)$ has a higher efficiency than the PMR without using catalyst materials.

\section{Conclusion}

Hydrogen fuel is believed that it will be a promising candidate to lead a new hydrogen economy. In this review paper, the hydrogen production key technologies are reviewed. The hydrogen production different technologies from both fossil and non-fossil fuels such as (water electrolysis, biomass, steam reforming, partial oxidation, auto thermal, pyrolysis, and plasma technology) are reviewed. The reforming and gasification technologies are the most mature hydrogen production technology. Water electrolysis can be combined with the renewable energy to get eco-friendly technology. Additionally, it is important to produce hydrogen from a wide range of feedstock. Currently, the maximum hydrogen fuel productions are registered from the steam reforming, gasification, and partial oxidation technologies using fossil fuels. The hydrogen production technology efficiencies are summarized in Table 13. These technologies still have challenges such as the total energy consumption and carbon emissions to the environment are too high. Ammonia decomposition using plasma technology without and with a catalyst to produce pure hydrogen is considered as a compared 


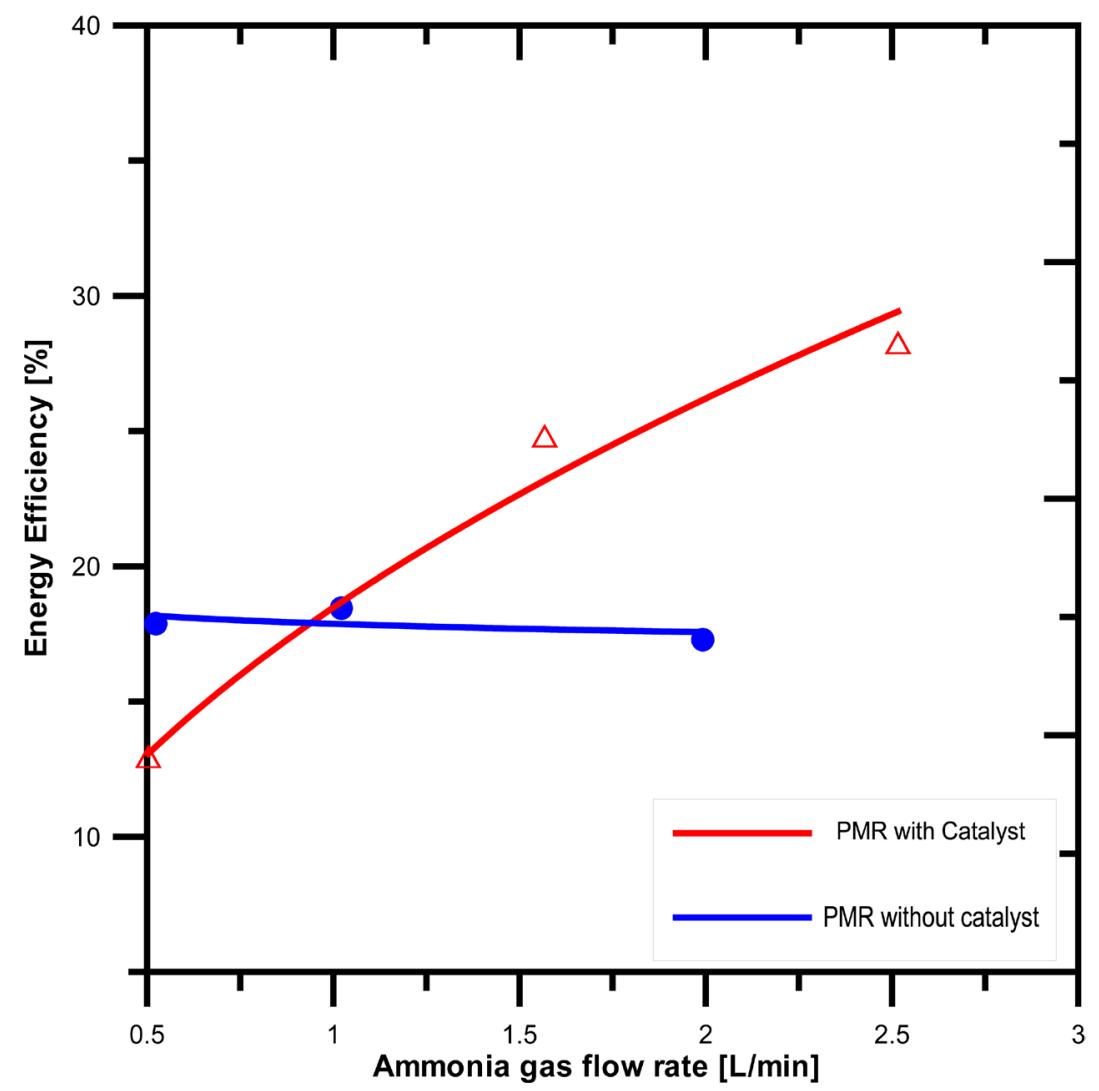

Figure 16. Comparison between PMR without and with a catalyst.

Table 13. Hydrogen Technology Efficiency summary table.

\begin{tabular}{|c|c|c|c|c|}
\hline Technology & Feed stock & Efficiency & Maturity & Reference \\
\hline Steam reforming & Hydrocarbons & $70 \%-85 \%$ & Commercial & [209] \\
\hline Partial Oxidation & Hydrocarbons & $60 \%-75 \%$ & Commercial & [209] \\
\hline Autothermal reforming & Hydrocarbons & $60 \%-75 \%$ & Near term & [209] \\
\hline Plasma reforming & Hydrocarbons & $9 \%-85 \%$ & Long term & [285] \\
\hline Aqueous phase reforming & Carbohydrates & $35 \%-55 \%$ & Med. Term & {$[321]$} \\
\hline Ammonia decomposition & Ammonia & $28.3 \%$ & Near Term & [320] \\
\hline Biomass gasification & Biomass & $35 \%-50 \%$ & Commercial & [106] [117] [322] \\
\hline Photolysis & Sunlight + Water & $0.5 \%$ & Long term & [323] \\
\hline Dark fermentation & Biomass & $60 \%-80 \%$ & Long term & [117] [163] \\
\hline Photo fermentation & Biomass + Sunlight & $0.1 \%$ & Long term & [117] [322] \\
\hline Microbial electrolysis cells & Biomass+ Electricity & $78 \%$ & Long term & {$[323]$} \\
\hline Alkaline electrolyzer & $\mathrm{H}_{2} \mathrm{O}+$ Electricity & $50 \%-60 \%$ & Commercial & [93] [322] \\
\hline PEM electrolyzer & $\mathrm{H}_{2} \mathrm{O}+$ Electricity & $55 \%-70 \%$ & Near term & [93] [322] \\
\hline Solid oxide electrolysis cells & $\mathrm{H}_{2} \mathrm{O}+$ Electricity+ Heat & $40 \%-60 \%$ & Med term & {$[106]$} \\
\hline Thermochemical water splitting & $\mathrm{H}_{2} \mathrm{O}+$ Heat & NA & Long term & - \\
\hline Photo electrochemical water splitting & $\mathrm{H}_{2} \mathrm{O}+$ Sunlight & $12.4 \%$ & Long term & [93] [129] \\
\hline
\end{tabular}


case study. It is shown that the efficiency of ammonia decomposition using a catalyst is obtained $28.3 \%$ which is higher than ammonia decomposition without the catalyst. It is concluded that hydrogen production from ammonia decomposition is a promising technology to produce $99.99 \%$ pure hydrogen. Hydrogen technologies still have different challenges which require a lot of cooperation between researchers and industrial side to increase the hydrogen production by using the developed technologies.

\section{Conflicts of Interest}

The authors declare no conflicts of interest regarding the publication of this paper.

\section{References}

[1] Hennicke, P. and Fischedick, M. (2006) Towards Sustainable Energy Systems: The Related Role of Hydrogen. Energy Policy, 34, 1260-1270.

https://doi.org/10.1016/j.enpol.2005.12.016

[2] Marbán, G. and Valdés-Solís, T. (2007) Towards the Hydrogen Economy? International Journal of Hydrogen Energy, 32, 1625-1637. https://doi.org/10.1016/j.ijhydene.2006.12.017

[3] Dutta, S. (2014) A Review on Production, Storage of Hydrogen and Its Utilization as an Energy Resource. Industrial and Engineering Chemistry, 20, 1148-1156. https://doi.org/10.1016/j.jiec.2013.07.037

[4] Kothari, R., Tyagi, V.V. and Pathak, A. (2010) Waste-to-Energy: A Way from Renewable Energy Sources to Sustainable Development. Renewable and Sustainable Energy Reviews, 14, 3164-3170. https://doi.org/10.1016/j.rser.2010.05.005

[5] Hübert, T., Boon-Brett, L., Black, G. and Banach, U. (2011) Hydrogen Sensors-A Review. Sensors and Actuators B: Chemical, 157, 329-352. https://doi.org/10.1016/j.snb.2011.04.070

[6] Ni, M., Leung, M.K.H., Sumathy, K. and Leung, D.Y.C. (2004) Water Electrolysis-A Bridge between Renewable Resources and Hydrogen. Proceedings of the International Hydrogen Energy Forum, 25-28 May 2004, Vol. 1: 475-480.

[7] Zeng, K. and Zhang, D. (2010) Recent Progress in Alkaline Water Electrolysis for Hydrogen Production and Applications. Progress in Energy and Combustion Science, 36, 307-326. https://doi.org/10.1016/j.pecs.2009.11.002

[8] Dunn, J. (2007) Hydrogen Futures: Toward a Sustainable Energy System. International Journal of Hydrogen Energy, 27, 235-264. https://doi.org/10.1016/S0360-3199(01)00131-8

[9] Satyapal, S., Petrovic, J., Read, C., Thomas, G. and Ordaz, G. (2007) The U.S. Department of Energy's National Hydrogen Storage Project: Progress towards Meeting Hydrogen-Powered Vehicle Requirements. Catalysis Today, 120, 246-256. https://doi.org/10.1016/j.cattod.2006.09.022

[10] Ni, M., Leung, M.K.H., Sumathy, K. and Leung, D.Y.C. (2006) Potential of Renewable Hydrogen Production for Energy Supply in Hong Kong. International Journal of Hydrogen Energy, 31, 1401-1412. https://doi.org/10.1016/j.ijhydene.2005.11.005

[11] Ahluwalia, R.K. and Wang, X. (2005) Direct Hydrogen Fuel Cell Systems for Hybrid Vehicles. Journal of Power Sources, 139, 152-164. 
[12] Gahleitner, G. (2013) Hydrogen from Renewable Electricity: An International Review of Power-to-Gas Pilot Plants for Stationary Applications. International Journal of Hydrogen Energy, 38, 2039-2061. https://doi.org/10.1016/j.ijhydene.2012.12.010

[13] Balta-Ozkan, N. and Baldwin, E. (2013) Spatial Development of Hydrogen Economy in a Low-Carbon UK Energy System. International Journal of Hydrogen Energy, 38, 1209-1224. https://doi.org/10.1016/j.ijhydene.2012.11.049

[14] Houghton, T. and Cruden, A. (2009) An Investment-Led Approach to Analysing the Hydrogen Energy Economy in the UK. International Journal of Hydrogen Energy, 34, 4454-4462. https://doi.org/10.1016/j.ijhydene.2008.12.041

[15] Pudukudy, M., Yaakob, Z., Mohammad, M., Narayanan, B. and Sopian, K. (2014) Renewable Hydrogen Economy in Asia Opportunities and Challenges: An Overview. Renewable and Sustainable Energy Reviews, 30, 743-757.

https://doi.org/10.1016/j.rser.2013.11.015

[16] Fernandes, T., Pimenta, R., Correas, L., García-Camús, J., Cabral, A., Reyes, F., et al. (2013) Platform for Promoting a Hydrogen Economy in Southwest Europe: The HYRREG Project. International Journal of Hydrogen Energy, 38, 7594-7598. https://doi.org/10.1016/j.ijhydene.2013.01.131

[17] Bleischwitz, R. and Bader, N. (2010) Policies for the Transition towards a Hydrogen Economy: The EU Case. Energy Policy, 38, 5388-5398.

https://doi.org/10.1016/j.enpol.2009.03.041

[18] Ball, M., Wietschel, M. and Rentz, O. (2007) Integration of a Hydrogen Economy into the German Energy System: An Optimizing Modelling Approach. International Journal of Hydrogen Energy, 32, 1355-1368.

https://doi.org/10.1016/j.ijhydene.2006.10.016

[19] Andrews, J. and Shabani, B. (2012) Where Does Hydrogen Fit in a Sustainable Energy Economy? Procedia Engineering, 49, 15-25. https://doi.org/10.1016/j.proeng.2012.10.107

[20] McLellan, B.C. (2009) Potential Opportunities and Impacts of a Hydrogen Economy for the Australian Minerals Industry. International Journal of Hydrogen Energy, 34, 3571-3577. https://doi.org/10.1016/j.ijhydene.2009.03.008

[21] Do Sacramento, E., Carvalho, P.C., de Lima, L. and Veziroglu, T. (2013) Feasibility Study for the Transition towards a Hydrogen Economy: A Case Study in Brazil. Energy Policy, 62, 3-9. https://doi.org/10.1016/j.enpol.2013.06.071

[22] Liu, H., Almansoori, A., Fowler, M. and Elkamel, A. (2012) Analysis of Ontario's Hydrogen Economy Demands from Hydrogen Fuel Cell Vehicles. International Journal of Hydrogen Energy, 37, 8905-8916. https://doi.org/10.1016/j.ijhydene.2012.03.029

[23] Hajimiragha, A., Fowler, M.W. and Canizares, C.A. (2009) Hydrogen Economy Transition in Ontario Canada Considering the Electricity Grid Constraints. International Journal of Hydrogen Energy, 34, 5275-5293. https://doi.org/10.1016/j.ijhydene.2009.04.063

[24] Ren, J., Gao, S., Tan, S. and Dong, L. (2015) Hydrogen Economy in China: Strengths, Weaknesses, Opportunities Threats Analysis and Strategies Prioritization. Renewable and Sustainable Energy Reviews, 41, 1230-1243. https://doi.org/10.1016/j.rser.2014.09.014

[25] Ren, J., Gao, S., Tan, S., Dong, L., Scipioni, A. and Mazzi, A. (2015) Role Prioritization of Hydrogen Production Technologies for Promoting Hydrogen Economy in the Current State of China. Renewable and Sustainable Energy Reviews, 41, 1217-1229. https://doi.org/10.1016/j.rser.2014.09.028 
[26] Lu, J., Zahedi, A., Yang, C., Wang, M. and Peng, B. (2013) Building the Hydrogen Economy in China: Drivers, Resources and Technologies. Renewable and Sustainable Energy Reviews, 23, 543-556. https://doi.org/10.1016/j.rser.2013.02.042

[27] Pelaez-Samaniego, M.R., Riveros-Godoy, G., Torres-Contreras, S., Garcia-Perez, T. and Albornoz-Vintimilla, E. (2014) Production and Use of Electrolytic Hydrogen in Ecuador towards a Low Carbon Economy. Energy, 64, 626-631. https://doi.org/10.1016/j.energy.2013.11.012

[28] Lee, D.-H. (2014) Development and Environmental Impact of Hydrogen Supply Chain in Japan: Assessment by the CGELCA Method in Japan with a Discussion of the Importance of Biohydrogen. International Journal of Hydrogen Energy, 39, 19294-19310. https://doi.org/10.1016/j.ijhydene.2014.05.142

[29] Chun, D., Woo, C., Seo, H., Chung, Y., Hong, S. and Kim, J. (2014) The Role of Hydrogen Energy Development in the Korean Economy: An Input-Output Analysis. International Journal of Hydrogen Energy, 39, 7627-7633. https://doi.org/10.1016/j.ijhydene.2014.03.058

[30] Gim, B. and Yoon, W.L. (2012) Analysis of the Economy of Scale and Estimation of the Future Hydrogen Production Costs at Onsite Hydrogen Refueling Stations in Korea. International Journal of Hydrogen Energy, 37, 19138-19145. https://doi.org/10.1016/j.ijhydene.2012.09.163

[31] Bae, J.H. and Cho, G.-L. (2010) A Dynamic General Equilibrium Analysis on Fostering a Hydrogen Economy in Korea. Energy Economics, 32, S57-S66. https://doi.org/10.1016/j.eneco.2009.03.010

[32] Milciuviene, S., Milcius, D. and Praneviciene, B. (2006) Towards Hydrogen Economy in Lithuania. International Journal of Hydrogen Energy, 31, 861-866. https://doi.org/10.1016/j.ijhydene.2005.08.005

[33] Ramírez-Salgado, J. and Estrada-Martínez, A. (2004) Roadmap towards a Sustainable Hydrogen Economy in Mexico. Journal of Power Sources, 129, 255-263. https://doi.org/10.1016/j.jpowsour.2003.11.054

[34] Leaver, J.D., Gillingham, K.T. and Leaver, L.H. (2009) Assessment of Primary Impacts of a Hydrogen Economy in New Zealand Using UniSyD. International Journal of Hydrogen Energy, 34, 2855-2865. https://doi.org/10.1016/j.ijhydene.2009.01.063

[35] Amoo, L.M. and Fagbenle, R.L. (2014) An Integrated Impact Assessment of Hydrogen as a Future Energy Carrier in Nigeria's Transportation, Energy and Power Sectors. International Journal of Hydrogen Energy, 39, 12409-12433.

https://doi.org/10.1016/j.ijhydene.2014.06.022

[36] Mirza, U.K., Ahmad, N., Harijan, K. and Majeed, T. (2009) A Vision for Hydrogen Economy in Pakistan. Renewable and Sustainable Energy Reviews, 13, 1111-1115. https://doi.org/10.1016/j.rser.2008.08.005

[37] Stygar, M. and Brylewski, T. (2013) Towards a Hydrogen Economy in Poland. International Journal of Hydrogen Energy, 38, 1-9. https://doi.org/10.1016/j.ijhydene.2012.10.056

[38] Murray, M.L., Seymour, E.H., Rogut, J. and Zechowska, S.W. (2008) Stakeholder Perceptions towards the Transition to a Hydrogen Economy in Poland. International Journal of Hydrogen Energy, 33, 20-27. https://doi.org/10.1016/j.ijhydene.2007.09.020

[39] Murray, M.L., Seymour, E.H. and Pimenta, R. (2007) Towards a Hydrogen Economy in Portugal. International Journal of Hydrogen Energy, 32, 3223-3229. https://doi.org/10.1016/j.ijhydene.2007.02.027 
[40] Iordache, I., Gheorghe, A.V. and Iordache, M. (2013) Towards a Hydrogen Economy in Romania: Statistics, Technical and Scientific General Aspects. International Journal of Hydrogen Energy, 38, 12231-12240. https://doi.org/10.1016/j.ijhydene.2013.07.034

[41] Leben, J. and Hočevar, S. (2012) Correlation between National Development Indicators and the Implementation of a Hydrogen Economy in Slovenia. International Journal of Hydrogen Energy, 37, 5468-5480.

https://doi.org/10.1016/j.ijhydene.2011.11.099

[42] Brey, J., Brey, R., Carazo, A., Contreras, I., Hernandez-Díaz, A. and Castro, A. (2007) Planning the Transition to a Hydrogen Economy in Spain. International Journal of Hydrogen Energy, 32, 1339-1346.

https://doi.org/10.1016/j.ijhydene.2006.10.014

[43] Brey, J., Brey, R., Carazo, A., Contreras, I., Hernandez-Díaz, A. and Gallardo, V. (2006) Designing a Gradual Transition to a Hydrogen Economy in Spain. Journal of Power Sources, 159, 1231-1240. https://doi.org/10.1016/j.jpowsour.2005.12.089

[44] Lee, D.-H., Hsu, S.-S., Tso, C.-T., Su, A. and Lee, D.-J. (2009) An Economy-Wide Analysis of Hydrogen Economy in Taiwan. Renewable Energy, 34, 1947-1954. https://doi.org/10.1016/j.renene.2008.12.006

[45] Lee, D.-H. and Lee, D.-J. (2008) Hydrogen Economy in Taiwan and Biohydrogen. International Journal of Hydrogen Energy, 33, 1607-1618. https://doi.org/10.1016/j.ijhydene.2007.09.028

[46] Lattin, W. and Utgikar, V. (2007) Transition to Hydrogen Economy in the United States: A 2006 Status Report. International Journal of Hydrogen Energy, 32, 3230-3237. https://doi.org/10.1016/j.ijhydene.2007.02.004

[47] Urbaniec, K., Friedl, A., Huisingh, D. and Claassen, P. (2010) Hydrogen for a Sustainable Global Economy. Journal of Cleaner Production, 18, S1-S3. https://doi.org/10.1016/j.jclepro.2010.05.010

[48] Blanchette, S. (2008) A Hydrogen Economy and Its Impact on the World as We Know It. Energy Policy, 36, 522-530. https://doi.org/10.1016/j.enpol.2007.09.029

[49] Penner, S.S. (2006) Steps toward the Hydrogen Economy. Energy, 31, 33-43. https://doi.org/10.1016/j.energy.2004.04.060

[50] Maack, M.K. and Skulason, J.B. (2005) Implementing the Hydrogen Economy. Journal of Cleaner Production, 14, 52-64. https://doi.org/10.1016/j.jclepro.2005.05.027

[51] Bertel, E. (2004) Nuclear Energy-The Hydrogen Economy. Nuclear Energy Agency News, 22, 10-13.

[52] Duffey, R. (2005) Green Atoms. Power Energy, 2, 8-12.

[53] Scott, D.S. (2007) Smelling Land: The Hydrogen Defense against Climate Catastrophe. Canadian Hydrogen Association, Ottawa.

[54] Veziroglu, T.N. and Barbir, F. (1998) Hydrogen Energy Technologies. UNIDO, Vienna.

[55] Veziroglu, T.N. (2000) Quarter Century of Hydrogen Movement 1974-2000. International Journal of Hydrogen Energy, 25, 1143-1150. https://doi.org/10.1016/S0360-3199(00)00038-0

[56] Dincer, I. and Zamfirescu, C. (2012) Sustainable Hydrogen Production Options and the Role of IAHE. International Journal of Hydrogen Energy, 37, 16266-16286. https://doi.org/10.1016/j.ijhydene.2012.02.133 
[57] Bockris J.O’M. (2002) The Origin of Ideas on a Hydrogen Economy and Its Solution to the Decay of the Environment. International Journal of Hydrogen Energy, 27, 731-740. https://doi.org/10.1016/S0360-3199(01)00154-9

[58] Sinigaglia, T., Lewiski, F., Martins, M.E.S. and Siluk, J.C.M. (2017) Production, Storage, Fuel Stations of Hydrogen and Its Utilization in Automotive Applications-A Review. International Journal of Hydrogen Energy, 42, 24597-24611. https://doi.org/10.1016/j.ijhydene.2017.08.063

[59] Barbir, F., Veziroglu, T.N. and Plass Jr., H.J. (1990) Environmental Damage Due to Fossil Fuel Use. International Journal of Hydrogen Energy, 15, 739-749. https://doi.org/10.1016/0360-3199(90)90005-J

[60] Baykara, S.Z. (2005) Hydrogen as Fuel: A Critical Technology? International Journal of Hydrogen Energy, 30, 545-553. https://doi.org/10.1016/j.ijhydene.2004.06.010

[61] Baykara, S.Z. (2005) Ecohealth Problems and Climate Change I: Anthropogenic Climate Change and Ecohealth: Worldwide Environmental Damage. Book of Invited Background Papers. IFSSH World Congress Health Challenges of the Third Millenium, Istanbul, 21-26 August 2005, 295-313.

[62] Veziroglu, T.N. (2005) Ecohealth Problems and Climate Change II: Permanent Solution to Environmental Problems: Hydrogen Energy System. Book of Invited Background Papers. IFSSH World Congress Health Challenges of the Third Millenium, Istanbul, 21-26 August 2005, 315-335.

[63] Veziroglu, T.N., Gurkan, I. and Padki, M.M. (1989) Remediation of Greenhouse Problem through Replacement of Fossil Fuels by Hydrogen. International Journal of Hydrogen Energy, 14, 257-266. https://doi.org/10.1016/0360-3199(89)90062-1

[64] U.S. Energy Information Administration April 2016. Monthly Energy Review. DOE/EIA-0035 (2016/04).

[65] Arup and Siemens (2016) Distributed Energy Systems: Flexible and Efficient Power for the New Energy Era.

https://www.arup.com/perspectives/publications/research/section/distributed-energ y-systems-flexible-and-efficient-power-for-the-new-energy-era

[66] Hefner, R.A., GHK Company (2007) The Age of Energy Gases (Fig. 1). China's Opportunity for Global Energy Leadership, Oklahoma City, 1-32.

[67] Japan's Energy 2017. http://www.enecho.meti.go.jp/ Source: [Other than Japan] Data of figures in 2015, IEA Energy Balance of OECD Countries (2017 edition), [Japan].

[68] Fri, R.W. and Savitz, M.L. (2014) Rethinking Energy Innovation and Social Science. Energy Research \& Social Science, 1, 183-187. https://doi.org/10.1016/j.erss.2014.03.010

[69] Mach, K. and Mastrandrea, M. (2014) Climate Change 2014: Impacts, Adaptation, and Vulnerability, Vol. 1. Cambridge University Press, Cambridge, New York, NY.

[70] Dincer, I. and Acar, C. (2018) Smart Energy Solutions with Hydrogen Options. International Journal of Hydrogen Energy, 43, 8579-8599. https://doi.org/10.1016/j.ijhydene.2018.03.120

[71] Dincer, I. and Acar, C. (2015) Review and Evaluation of Hydrogen Production Methods for Better Sustainability. International Journal of Hydrogen Energy, 40, 11094-11111. https://doi.org/10.1016/j.ijhydene.2014.12.035

[72] Suleman, F., Dincer, I. and Agelin-Chaab, M. (2016) Comparative Impact Assessment Study of Various Hydrogen Production Methods in Terms of Emissions. International Journal of Hydrogen Energy, 41, 8364-8375. 
https://doi.org/10.1016/j.ijhydene.2015.12.225

[73] Suleman, F., Dincer, I. and Agelin-Chaab, M. (2015) Environmental Impact Assessment and Comparison of Some Hydrogen Production Options. International Journal of Hydrogen Energy, 40, 6976-6987.

https://doi.org/10.1016/j.ijhydene.2015.03.123

[74] Mandal, T.K. and Gregory, D.H. (2009) Hydrogen: A Future Energy Vector for Sustainable Development. Proceedings of the Institution of Mechanical Engineers Part C: Journal of Mechanical Engineering Science, 224, 539-558.

[75] Bicer, Y. and Dincer, I. (2018) Environmental Impact Categories of Hydrogen and Ammonia Driven Transoceanic Maritime Vehicles: A Comparative Evaluation. International Journal of Hydrogen Energy, 43, 4583-4596.

https://doi.org/10.1016/j.ijhydene.2017.07.110

[76] Xie, M., Ruan, J., Bai, W., Qiao, Q., Bai, L., Zhang, J., Li, H., Lv, F. and Fu, H. (2018) Pollutant Payback Time and Environmental Impact of Chinese Multi Crystalline Photovoltaic Production Based on Life Cycle Assessment. Journal of Cleaner Production, 184, 648-659. https://doi.org/10.1016/j.jclepro.2018.02.290

[77] Acar, C. and Dincer, I. (2014) Comparative Assessment of Hydrogen Production Methods from Renewable and Non-Renewable Sources. International Journal of Hydrogen Energy, 39, 1-12. https://doi.org/10.1016/j.ijhydene.2013.10.060

[78] Chaubey, R., Sahu, S., James, O.O. and Maity, S. (2013) A Review on Development of Industrial Processes and Emerging Techniques for Production of Hydrogen from Renewable and Sustainable Sources. Renewable and Sustainable Energy Reviews, 23, 443-462. https://doi.org/10.1016/j.rser.2013.02.019

[79] Dincer, I. (2012) Green Methods for Hydrogen Production. International Journal of Hydrogen Energy, 37, 1954-1971. https://doi.org/10.1016/j.ijhydene.2011.03.173

[80] Holladay, J.D., Hu, J., King, D.L. and Wang, Y. (2009) An Overview of Hydrogen Production Technologies. Catalysis Today, 139, 244-260.

https://doi.org/10.1016/j.cattod.2008.08.039

[81] Freedom CAR \& Fuel Partnership, Hydrogen Production Overview of Technology Options. https://www1.eere.energy.gov/hydrogenandfuelcells/pdfs/h2_tech_roadmap.pdf

[82] Mueller-Langer, F., Tzimas, E., Kaltchmitt, M. and Peteves, S. (2007) Techno-Economic Assessment of Hydrogen Production Processes for the Hydrogen Economy for the Short and Medium term. International Journal of Hydrogen Energy, 32, 3797-3810. https://doi.org/10.1016/j.ijhydene.2007.05.027

[83] Ngoh, S.K. and Njomo, D. (2012) An Overview of Hydrogen Gas Production from Solar Energy. Renewable and Sustainable Energy Reviews, 16, 6782-6792. https://doi.org/10.1016/j.rser.2012.07.027

[84] Trainham, J.A., Newman, J., Bonino, C.A., Hoertz, P.G. and Akunuri, N. (2012) Whither Solar Fuels? Current Opinion in Chemical Engineering, 1, 204-210. https://doi.org/10.1016/j.coche.2012.04.001

[85] Yadav, D. and Banerjee, R. (2016) A Review of Solar Thermochemical Processes. Renewable and Sustainable Energy Reviews, 54, 497-532. https://doi.org/10.1016/j.rser.2015.10.026

[86] Koroneos, C. and Rovas, D. (2012) A Review on Exergy Comparison of Hydrogen Production Method from Renewable Energy Sources. Energy \& Environmental Science, 5, 6640-6651. https://doi.org/10.1039/c2ee01098d

[87] Yılmaz, F., Balta, M.T. and Selbas, R. (2016) A Review of Solar Based Hydrogen 
Production Methods. Renewable and Sustainable Energy Reviews, 56, 171-178. https://doi.org/10.1016/j.rser.2015.11.060

[88] Abanades, A. (2012) The Challenge of Hydrogen Production for the Transition to a $\mathrm{CO}_{2}$-Free Economy. Agronomy Research Biosystem Engineering Special Issue, 1, 11-16.

[89] Bartels, J.R., Pate, M.B. and Olson, N.K. (2010) An Economic Survey of Hydrogen Production from Conventional and Alternative Energy Sources. International Journal of Hydrogen Energy, 35, 8371-8384. https://doi.org/10.1016/j.ijhydene.2010.04.035

[90] Baykara, S.Z. (2018) Hydrogen: A Brief Overview on Its Sources, Production and Environmental Impact. International Journal of Hydrogen Energy, 43, 10605-10614. https://doi.org/10.1016/j.ijhydene.2018.02.022

[91] Chang, R. (2002) Chemistry. McGraw Hill, Boston.

[92] Dincer, I. and Zamfirescu, C. (2011) Sustainable Energy Systems and Applications. Springer Science \& Business Media.

[93] Turner, J., Sverdrup, G., Mann, M.K., Maness, P.-C., Kroposki, B., Ghirardi, M., Evans, R.J. and Blake, D. (2008) Renewable Hydrogen Production. International Journal of Hydrogen Energy, 32, 379-407.

[94] Norbeck, J.M., Heffel, J.W., Durbin, T.D., Tabbara, B., Bowden, J.M. and Montani, M.C. (1996) Hydrogen Fuel for Surface Transportation. Society of Automotive Engineers Inc., Warrendale, PA, 548. https://doi.org/10.4271/R-160

[95] Pettersson, J., Ramsey, B. and Harrison, D. (2006) A Review of the Latest Developments in Electrodes for Unitised Regenerative Polymer Electrolyte Fuel Cells. Journal of Power Sources, 157, 28-34. https://doi.org/10.1016/j.jpowsour.2006.01.059

[96] Grigoriev, S.A., Porembsky, V.I. and Fateev, V.N. (2006) Pure Hydrogen Production by PEM Electrolysis for Hydrogen Energy. International Journal of Hydrogen Energy, 31, 171-175. https://doi.org/10.1016/j.ijhydene.2005.04.038

[97] Janssen, H., Bringmann, J.C., Emonts, B. and Schroeder, V. (2004) Safety-Related studies on Hydrogen Production in High-Pressure Electrolysers. International Journal of Hydrogen Energy, 29, 759-770. https://doi.org/10.1016/j.ijhydene.2003.08.014

[98] Bradley, M.J. (2000) Future Wheels Interviews with 44 Global Experts on the Future of Fuel Cells for Transportation and Fuel Cell Infrastructure and a Fuel Cell Primer. Northeast Advanced Vehicle Consortium, Boston, MA, p. 89.

[99] Koroneos, C., Dompros, A., Roumbas, G. and Moussiopoulos, N. (2004) Life Cycle Assessment of Hydrogen Fuel Production Processes. International Journal of Hydrogen Energy, 29, 1443-1450. https://doi.org/10.1016/j.ijhydene.2004.01.016

[100] Aroutiounian, V.M., Arakelyan, V.M. and Shahnazaryan, G.E. (2005) Metal Oxide Photoelectrodes for Hydrogen Generation Using Solar Radiation-Driven Water Splitting. Solar Energy, 78, 581-592. https://doi.org/10.1016/j.solener.2004.02.002

[101] Sujatha Devi, P., Das Sharma, A. and Maiti, H.S. (2004) Solid Oxide Fuel Cell Materials: A Review. Transactions of the Indian Ceramic Society, 63, 75-98. https://doi.org/10.1080/0371750X.2004.11012140

[102] Erickson, P.A. and Goswami, D.Y. (2001) Hydrogen from Solar Energy: An Overview of Theory and Current Technological Status. In: Proceedings of the Intersociety Energy Conversion Engineering Conference, Institute of Electrical and Electronics Engineers Inc., Savannah, GA, 573-580.

[103] Bhandari, R., Trudewind, C.A. and Zapp, P. (2014) Life Cycle Assessment of Hy- 
drogen Production via Electrolysis Review. Journal of Cleaner Production, 85, 151-163. https://doi.org/10.1016/j.jclepro.2013.07.048

[104] Ball, M. and Wietschel, M. (2009) The Hydrogen Economy: Opportunities and Challenges. Cambridge University Press, Cambridge. https://doi.org/10.1017/CBO9780511635359

[105] Turner, J., Sverdrup, G., Mann, M.K., Maness, P.-C., Kroposki, B., Ghirardi, M., et al. (2008) Renewable Hydrogen Production. International Journal of Energy Research, 32, 379-407. https://doi.org/10.1002/er.1372

[106] National Academy of Science (2004) The Hydrogen Economy: Opportunities, Costs, Barriers, and R\&D Needs. National Academies Press, Washington DC.

[107] Ursua, A., Gandia, L.M. and Sanchis, P. (2012) Hydrogen Production from Water Electrolysis: Current Status and Future Trends. Proceedings of the IEEE, 100, 410-426. https://doi.org/10.1109/JPROC.2011.2156750

[108] Hino, R., Haga, K., Aita, H. and Sekita, K. (2004) R\&D on Hydrogen Production by High-Temperature Electrolysis of Steam. Nuclear Engineering and Design, 233, 363-375. https://doi.org/10.1016/j.nucengdes.2004.08.029

[109] Utgikar, V. and Thiesen, T. (2006) Life Cycle Assessment of High Temperature Electrolysis for Hydrogen Production via Nuclear Energy. International Journal of Hydrogen Energy, 31, 939-944. https://doi.org/10.1016/j.ijhydene.2005.07.001

[110] Goswami, D.Y., Mirabal, S.T., Goel, N. and Ingley, H.A. (2003) Fuel Cell Science, Engineering and Technology, A Review of Hydrogen Production Technologies, American Society of Mechanical Engineers, New York, NY/Rochester, NY, 61-74.

[111] Schultz, K.R. (2003) Production of Hydrogen by Fusion Energy: A Review and Perspective. Fusion Science and Technology, 44, 393-399. https://doi.org/10.13182/FST03-A366

[112] AlZahrania, A.A. and Dincer, I. (2018) Modeling and Performance Optimization of a Solid Oxide Electrolysis System for Hydrogen Production. Applied Energy, 225, 471-485. https://doi.org/10.1016/j.apenergy.2018.04.124

[113] Baykara, S.Z. (2004) Hydrogen Production by Direct Solar Thermal Decomposition of Water, Possibilities for Improvement of Process Efficiency. International Journal of Hydrogen Energy, 29, 1451-1458. https://doi.org/10.1016/j.ijhydene.2004.02.014

[114] Polat, Y. (2018) Comments on "Reduced Band Gap \& Charge Recombination Rate in Se Doped a- $\mathrm{Bi}_{2} \mathrm{O}_{3}$ Leads to Enhanced Photo Electrochemical and Photocatalytic Performance: Theoretical \& Experimental Insight" [Int J Hydrogen Energy 42 (2017) 20638-20648]. International Journal of Hydrogen Energy, 43, 468-469. https://doi.org/10.1016/j.ijhydene.2017.07.011

[115] Yalcin, S. (1989) A Review of Nuclear Hydrogen Production. International Journal of Hydrogen Energy, 14, 551-561. https://doi.org/10.1016/0360-3199(89)90113-4

[116] Sharma, S. and Ghoshal, S.K. (2015) Hydrogen the Future Transportation Fuel: From Production to Applications. Renewable and Sustainable Energy Reviews, 43, 1151-1158. https://doi.org/10.1016/j.rser.2014.11.093

[117] Ogden, J.M. (n.d.) Review of Small Stationary Reformers for Hydrogen Production, Report to the International Energy Agency. https://afdc.energy.gov/files/pdfs/31948.pdf

[118] U.S. Department of Energy Hydrogen (2007) Fuel Cells and Infrastructure Technologies Program, Multi-Year Research, Development and Demonstration Plan. U.S. Department of Energy.

[119] Lewis, M., Serban, M., Basco, J. and Figueroa, J. (2003) Low Temperature Thermo- 
chemical Cycle Development, Chicago, IL.

[120] Orhan, M.F., Dincer, I. and Rosen, M.A. (2012) Investigation of an Integrated Hydrogen Production System Based on Nuclear and Renewable Energy Sources: A New Approach for Sustainable Hydrogen Production via Copper-Chlorine Thermochemical Cycles. International Journal of Energy Research, 36, 1388-1394. https://doi.org/10.1002/er.1926

[121] Funk, J.E. (2001) Thermochemical Hydrogen Production: Past and Present. International Journal of Hydrogen Energy, 26, 185-190. https://doi.org/10.1016/S0360-3199(00)00062-8

[122] Kothari, R., Buddhi, D. and Sawhney, R. (2008) Comparison of Environmental and Economic Aspects of Various Hydrogen Production Methods. Renewable and Sustainable Energy Reviews, 12, 553-563. https://doi.org/10.1016/j.rser.2006.07.012

[123] Dincer, I. and Zamfirescu, C. (2011) Sustainable Energy Systems and Applications. Springer Science \& Business Media.

[124] Bashiri, R., Mohamed, N.M., Kait, C.F. and Sufian, S. (2015) Hydrogen Production from Water Photosplitting Using $\mathrm{Cu} / \mathrm{TiO} 2$ Nanoparticles: Effect of Hydrolysis Rate and Reaction Medium. International Journal of Hydrogen Energy, 40, 6021-6037. https://doi.org/10.1016/j.ijhydene.2015.03.019

[125] Peng, S., Zeng, X. and Li, Y. (2015) Titanate Nanotube Modified with Different Nickel Precursors for Enhanced Eosin y-Sensitized Photocatalytic Hydrogen Evolution. International Journal of Hydrogen Energy, 40, 6038-6049. https://doi.org/10.1016/j.ijhydene.2015.03.055

[126] Nakata, K. and Fujishima, A. (2012) $\mathrm{TiO}_{2}$ Photocatalysis: Design and Applications. Journal of Photochemistry and Photobiology C: Photochemistry Reviews, 13, 169-189. https://doi.org/10.1016/j.jphotochemrev.2012.06.001

[127] Li, C., Yuan, J., Han, B. and Shangguan, W. (2011) Synthesis and Photochemical Performance of Morphology-Controlled CdS Photocatalysts for Hydrogen Evolution under Visible Light. International Journal of Hydrogen Energy, 36, 4271-4279. https://doi.org/10.1016/j.ijhydene.2011.01.022

[128] Sathish, M., Viswanathan, B. and Viswanath, R. (2006) Alternate Synthetic Strategy for the Preparation of CdS Nanoparticles and Its Exploitation for Water Splitting. International Journal of Hydrogen Energy, 31, 891-898. https://doi.org/10.1016/j.ijhydene.2005.08.002

[129] Turner, J., Deutsch, T., Head, J. and Vallett, P. (2007) Photoelectrochemical water systems for H2 production. In: DOE Hydrogen Program Annual Merit Review, U.S. Department of Energy, Washington DC. http://www.hydrogen.energy.gov/pdfs/review07/pd_10_turner.pdf

[130] Akikusa, J. and Khan, S.U.M. (2002) Photoelectrolysis of Water to Hydrogen in $\mathrm{p}-\mathrm{SiC} / \mathrm{Pt}$ and $\mathrm{p}-\mathrm{SiC} / \mathrm{n}-\mathrm{TiO}_{2}$ Cells. International Journal of Hydrogen Energy, 27, 863-870. https://doi.org/10.1016/S0360-3199(01)00191-4

[131] Mor, G.K., Varghese, O.K., Paulose, M., Shankar, K. and Grimes, C.A. (2006) A Review on Highly Ordered, Vertically Oriented $\mathrm{TiO}_{2}$ Nanotube Arrays: Fabrication, Material Properties, and Solar Energy Applications. Solar Energy Materials and Solar Cells, 90, 2011-2075. https://doi.org/10.1016/j.solmat.2006.04.007

[132] Licht, S., Wang, B., Mukerji, S., Soga, T., Umeno, M. and Tributsch, H. (2001) Over 18\% Solar Energy Conversion to Generation of Hydrogen Fuel; Theory and Experiment for Efficient Solar Water Splitting. International Journal of Hydrogen Energy, 26, 653-659. https://doi.org/10.1016/S0360-3199(00)00133-6 
[133] Yamada, O. (2006) Generation of Hydrogen Gas by Reforming Biomass with Superheated Steam. Thin Solid Films, 509, 207-211. https://doi.org/10.1016/j.tsf.2005.09.174

[134] Steinberg, M. (2004) A Highly Efficient Combined Cycle Fossil and Biomass Fuel Power Generation and Hydrogen Production Plant with Zero $\mathrm{CO}_{2}$ Emission. In; Fuel Cell Science, Engineering and Technology-2004, American Society of Mechanical Engineers, New York /Rochester, NY, 401-408.

[135] Chum, H.L. and Overend, R.P. (2001) Biomass and Renewable Fuels. Fuel Processing Technology, 71, 187-195. https://doi.org/10.1016/S0378-3820(01)00146-1

[136] Satrio, J.A., Shanks, B.H. and Wheelock, T.D. (2004) Application of Combined Catalyst/Sorbent on Hydrogen Generation from Biomass Gasification. In: AIChE Annual Meeting Conference Proceedings, American Institute of Chemical Engineers, New York, NY, United States/Austin, TX, United States, 297-301.

[137] Lu, P., Xiong, Z., Wang, T., Chang, J., Wu, C. and Chen, Y. (2003) Biomass Gasification in a Fluidized Bed Toproduce Hydrogen Rich Gas. Taiyangneng Xuebaol Acta Energiae Solaris Sinica, 24, 758-764.

[138] Jacobsen, H. (2004) "Heterogreeneous" Chemistry: Catalysts for Hydrogen Production from Biomass. Angewandte Chemie International Edition, 43, 1912-1914. https://doi.org/10.1002/anie.200301700

[139] Chen, G., Lv, X., Li, Q., Deng, N. and Jiao, L. (2004) Production of Hydrogen-Rich Gas through Pyrolysis of Biomass in a Two Stage Reactor. In: Proceedings of the ASME Turbo Expo 2004, American Society of Mechanical Engineers, New York/Vienna, 711-721.

[140] Weber, G., Fu, Q. and Wu, H. (2006) Energy Efficiency of an Integrated Process Based on Gasification for Hydrogen Production from Biomass. Developments in Chemical Engineering and Mineral Processing, 14, 33-49.

[141] Vasileiadis, S. and Ziaka-Vasileiadou, Z. (2004) Biomass Reforming Process for Integrated Solid Oxide-Fuel Cell Power Generation. Chemical Engineering Science, 59, 4853-4859. https://doi.org/10.1016/j.ces.2004.07.071

[142] Levin, D.B., Zhu, H., Beland, M., Cicek, N. and Holbein, B.E. (2007) Potential for Hydrogen and Methane Production from Biomass Residues in Canada. Bioresource Technology, 98, 654-660. https://doi.org/10.1016/j.biortech.2006.02.027

[143] Wood, A. (2002) Chemical Week, 164, 30.

[144] Asadullah, M., Ito, S.-I., Kunimori, K., Yamada, M. and Tomishige, K. (2002) Energy Efficient Production of Hydrogen and Syngas from Biomass: Development of Low-Temperature Catalytic Process for Cellulose Gasification. Environmental Science and Technology, 36, 4476-4481. https://doi.org/10.1021/es020575r

[145] Demirbas, M.F. (2006) Hydrogen from Various Biomass Species via Pyrolysis and Steam Gasification Processes. Energy Sources, 28, 245-252. https://doi.org/10.1080/009083190890003

[146] Demirbas, A. (2001) Yields of Hydrogen of Gaseous Products via Pyrolysis from Selected Biomass Samples. Fuel, 80, 1885-1891. https://doi.org/10.1016/S0016-2361(01)00070-9

[147] Canter, N. (2004) Development of a Lean, Green Automobile. Tribology and Lubrication Technology, 60, 14-15.

[148] Demirbas, A. and Demirbas, M.F. (2003) Biomass and Wastes: Upgrading Alternative Fuels. Energy Sources, 25, 317-329. https://doi.org/10.1080/00908310390142352 
[149] Demirbas, A. (2004) Combustion Characteristics of Different Biomass Fuels. Progress in Energy and Combustion Science, 30, 219-230. https://doi.org/10.1016/j.pecs.2003.10.004

[150] Bagchi, B., Rawlston, J., Counce, R.M., Holmes, J.M. and Bienkowski, P.R. (2006) Green Production of Hydrogen from Excess Biosolids Originating from Municipal Waste Water Treatment. Separation Science and Technology, 41, 2613-2628. https://doi.org/10.1080/01496390600745743

[151] Paterek, J.R. (2005) Method and Apparatus for Hydrogen Production from Organic Wastes and Manure. Industrial Bioprocessing, 27, 5.

[152] Guo, Y.S., Fang, W.J. and Lin, R.S. (2005) Coking-Inhibition of Pyrolysis-Cracking of Endothermic Hydrocarbon Fuel. Journal of Zhejiang University (Engineering Science), 39, 538-541.

[153] Salakhov, I.I., Ekimova, A.M., Eiyatdinov, A.S., Diyarov, I.N., Gil'manov, K.K. and Shangareeva, A.R. (2005) Effect of Feedstock Hydrocarbon Composition on the Distribution of Products of Initiated Pyrolysis. Chemistry and Technology of Fuels and Oils, 41, 386-394. https://doi.org/10.1007/s10553-005-0084-6

[154] Kirtay, E. (2011) Recent Advances in Production of Hydrogen from Biomass. Energy Conversion and Management, 52, 1778-1789. https://doi.org/10.1016/j.enconman.2010.11.010

[155] Hao, X. and Guo, L. (2002) Review on Investigation of Hydrogen Production by Biomass Catalytic Gasification in Supercritical Water. Journal of Chemical Industry and Engineering (China), 53, 221-228.

[156] Wills, J. (2006) Biohydrogen Pathways. Fuel Cell Review, 2, 23-26.

[157] Fan, Y.T., Zhang, Y.H., Zhang, S.F., Hou, H.W. and Ren, B.Z. (2006) Efficient Conversion of Wheat Straw Wastes into Biohydrogen Gas by Cow Dung Compost. Bioresource Technology, 97, 500-505. https://doi.org/10.1016/j.biortech.2005.02.049

[158] Shu, Y.W., Chi, N.L., Jian, S.C. and Jo, S.C. (2005) Biohydrogen Production with Anaerobic Sludge Immobilized by Ethylene-Vinyl Acetate Copolymer. International Journal of Hydrogen Energy, 30, 1375-1381. https://doi.org/10.1016/j.ijhydene.2004.09.011

[159] Cai, M., Liu, J. and Wei, Y. (2004) Enhanced Biohydrogen Production from Sewage Sludge with Alkaline Pretreatment. Environmental Science and Technology, 38, 3195-3202. https://doi.org/10.1021/es0349204

[160] Levin, D.B., Pitt, L. and Love, M. (2004) Biohydrogen Production: Prospects and Limitations to Practical Application. International Journal of Hydrogen Energy, 29, 173-185. https://doi.org/10.1016/S0360-3199(03)00094-6

[161] Gavala, H.N., Skiadas, I.V., Ahring, B.K. and Lyberatos, G. (2005) Potential for Biohydrogen and Methane Production from Olive Pulp. Water Science and Technology, 52, 209-215. https://doi.org/10.2166/wst.2005.0519

[162] Khanal, S.K., Chen, W.-H., Li, L. and Sung, S. (2006) Biohydrogen Production in Continuous-Flow Reactor Using Mixed Microbial Culture. Water Environment Research, 78, 110-117. https://doi.org/10.2175/106143005X89562

[163] Kovács, K.L., Maróti, G. and Rákhely, G. (2006) A Novel Approach for Biohydrogen Production. International Journal of Hydrogen Energy, 31, 1460-1468.

https://doi.org/10.1016/j.ijhydene.2006.06.011

[164] Bélafi-Bako, K., Búcsu, D., Pientka, Z., Bálint, B., Herbel, Z., Kovács, K.L. and Wessling, M. (2006) Integration of Biohydrogen Fermentation and Gas Separation Processes to Recover and Enrich Hydrogen. International Journal of Hydrogen 
Energy, 31, 1490-1495. https://doi.org/10.1016/j.ijhydene.2006.06.022

[165] Nath, K. and Das, D. (2004) Biohydrogen Production as a Potential Energy Resource-Present State-of-Art. Journal of Scientific and Industrial Research, 63, 729-738.

[166] Takeuchi, Y. and Amao, Y. (2005) Biohydrogen Production from Sucrose Using the Light-Harvesting Function of Zinc Chlorophyll-a. Bulletin of the Chemical Society of Japan, 78, 622-625. https://doi.org/10.1246/bcsj.78.622

[167] Han, S.-K. and Shin H.-S. (2004) Biohydrogen Production by Anaerobic Fermentation of Food Waste. International Journal of Hydrogen Energy, 29, 569-577. https://doi.org/10.1016/j.ijhydene.2003.09.001

[168] Redwood, M.D. and Macaskie, L.E. (2006) A Two-Stage, Two-Organism Process for Biohydrogen from Glucose. International Journal of Hydrogen Energy, 31, 1514-1521. https://doi.org/10.1016/j.ijhydene.2006.06.018

[169] Bálint, B., Bagi, Z., Tóth, A., Rákhely, G., Perei, K. and Kovács, K.L. (2005) Utilization of Keratin-Containing Biowaste to Produce Biohydrogen. Applied Microbiology and Biotechnology, 69, 404-410. https://doi.org/10.1007/s00253-005-1993-3

[170] Zhao, Y.S., Teng, X.F., Zhang, P. and Tan, T.W. (2005) Biohydrogen Produced through Mixture Anaerobic Biological Fermentation. Beijing Huagong Daxue $\mathrm{Xu}$ ebao (Ziran Kexueban)/Journal of Beijing University of Chemical Technology (Natural Science Edition), 32, 1-4.

[171] Chang, J.-S., Lee, K.-S. and Lin, P.-J. (2002) Biohydrogen Production with Fixed-Bed Bioreactors. International Journal of Hydrogen Energy, 27, 1167-1174. https://doi.org/10.1016/S0360-3199(02)00130-1

[172] Van Ginkel, S.W., Oh, S.-E. and Logan, B.E. (2005) Biohydrogen Gas Production from Food Processing and Domestic Wastewaters. International Journal of Hydrogen Energy, 30, 1535-1542. https://doi.org/10.1016/j.ijhydene.2004.09.017

[173] Amao, Y. and Nakamura, N. (2006) Biohydrogen Production with the Light-Harvesting Function of Grana from Spirulina and Colloidal Platinum. International Journal of Hydrogen Energy, 31, 39-42. https://doi.org/10.1016/j.ijhydene.2005.03.009

[174] Ren, N.Q., Li, Y.F., Zadsar, M., Hu, L. and Li, J.Z. (2005) Biological Hydrogen Production in China: Past, Present and Future. ASME International Solar Energy Conference, 663-666.

[175] Vijayaraghavan, K. and Ahmad, D. (2006) Biohydrogen Generation from Palm oil Mill Effluent Using Anaerobic Contact Filter. International Journal of Hydrogen Energy, 31, 1284-1291. https://doi.org/10.1016/j.ijhydene.2005.12.002

[176] Kim, S.-H., Han, S.-K. and Shin, H.-S. (2004) Feasibility of Biohydrogen Production by Anaerobic Co-Digestion of Food Waste and Sewage Sludge. International Journal of Hydrogen Energy, 29, 1607-1616. https://doi.org/10.1016/j.ijhydene.2004.02.018

[177] Kotsopoulos, T.A., Zeng, R.J. and Angelidaki, I. (2006) Biohydrogen Production in Granular Up-Flow Anaerobic Sludge Blanket (UASB) Reactors with Mixed Cultures under Hyper-Thermophilic Temperature $\left(70^{\circ} \mathrm{C}\right)$. Biotechnology and Bioengineering, 94, 296-302. https://doi.org/10.1002/bit.20844

[178] Vijayaraghavan, K., Ahmad, D. and Ibrahim, M.K.B. (2006) Biohydrogen Generation from Jackfruit Peel Using Anaerobic Contact Filter. International Journal of Hydrogen Energy, 31, 569-579. https://doi.org/10.1016/j.ijhydene.2005.06.006

[179] Horváth, R., Orosz, T., Bálint, B., Wessling, M., Koops, G.H., Kapantaidakis, G.C. 
and Bélafi-Báko, K. (2004) Application of Gas Separation to Recover Biohydrogen Produced by Thiocapsa roseopersicina. Desalination, 163, 261-265. https://doi.org/10.1016/S0011-9164(04)90198-1

[180] Franchi, E., Tosi, C., Scolla, G., Della Penna, G., Rodriguez, F. and Pedroni, P.M. (2004) Metabolically Engineered Rhodobacter sphaeroides RV Strains for Improved Biohydrogen Photoproduction Combined with Disposal of Food Wastes. Marine Biotechnology, 6, 552-565. https://doi.org/10.1007/s10126-004-1007-y

[181] Vignais, P.M., Magnin, J.-P. and Willison, J.C. (2006) Increasing Biohydrogen Production by Metabolic Engineering. International Journal of Hydrogen Energy, 31, 1478-1483. https://doi.org/10.1016/j.ijhydene.2006.06.013

[182] Lee, K.-S., Lo, Y.-S., Lo, Y.-C., Lin, P.-J. and Chang, J.-S. (2004) Operation Strategies for Biohydrogen Production with a High-Rate Anaerobic Granular Sludge Bed Bioreactor. Enzyme and Microbial Technology, 35, 605-612. https://doi.org/10.1016/j.enzmictec.2004.08.013

[183] Carrieri, D., Kolling, D., Ananyev, G. and Dismukes, G.C. (2006) Prospecting for Biohydrogen Fuel. Industrial Biotechnology, 2, 133-137. https://doi.org/10.1089/ind.2006.2.133

[184] Hawkes, F.R., Hussy, I., Kyazze, G., Dinsdale, R. and Hawkes, D.L. (2007) Continuous Dark Fermentative Hydrogen Production by Mesophilic Microflora: Principles and Progress. International Journal of Hydrogen Energy, 32,172-184. https://doi.org/10.1016/j.ijhydene.2006.08.014

[185] Kapdan, I.K. and Kargi, F. (2006) Bio-Hydrogen Production from Waste Materials. Enzyme and Microbial Technology, 38, 569-582. https://doi.org/10.1016/j.enzmictec.2005.09.015

[186] Cherryman, S., Maddy, J., Hawkes, F., Hawkes, D., Dinsdale, R., Guwy, A., et al. (2004) Hydrogen and Wales. University of Glamorgan, Pontypridd, Wales.

[187] Dincer, I. and Acar, C. (2015) A Review on Clean Energy Solutions for Better Sustainability. International Journal of Energy Research, 39, 585-606. https://doi.org/10.1002/er.3329

[188] Guwy, A., Dinsdale, R., Kim, J., Massanet-Nicolau, J. and Premier, G. (2011) Fermentative Biohydrogen Production Systems Integration. Bioresource Technology, 102, 8534-8542. https://doi.org/10.1016/j.biortech.2011.04.051

[189] Wilhelm, D.J., Simbeck, D.R., Karp, A.D. and Dickenson, R.L. (2001) Syngas Production for Gas-to-Liquids Applications: Technologies, Issues and Outlook. Fuel Processing Technology, 71, 139-148. https://doi.org/10.1016/S0378-3820(01)00140-0

[190] Holladay, J., Jones, E., Palo, D.R., Phelps, M., Chin, Y.-H., Dagle, R., Hu, J., Wang Y. and Baker, E. (2003) Miniature Fuel Processors for Portable Fuel Cell Power Supplies. In: Proceedings of the Materials Research Society Symposium, Materials Research Society, Boston, MA, 429-434.

[191] R.M. Navarro, M.A. Pen a, J.L.G. Fierro. Hydrogen Production Reactions from Carbon Feedstocks: Fossil Fuels and Biomass. Chemical Reviews 2007, 107(10): 3952-91. https://doi.org/10.1021/cr0501994

[192] Farrauto, R., Hwang, S., Shore, L., Ruettinger, W., Lampert, J., Giroux, T., Liu, Y. and Ilinich, O. (2003) New Material Needs for Hydrocarbon Fuel Processing: Generating Hydrogen for the PEM Fuel Cell. Annual Review of Materials Research, 33, 1-27. https://doi.org/10.1146/annurev.matsci.33.022802.091348

[193] King, D.L., Brooks, K.P., Fischer, C.M., Pederson, L., Rawlings, G., Stenkamp, S.V., 
TeGrotenhuis, W., Wegeng, R. and Whyatt, G.A. (2005) Fuel Reformation: Catalyst Requirements in Microchannel Architectures. In: Wang, Y. and Holladay, J.D., Eds., Microreactor Technology and Process Intensification, ACS, Washington DC, 119-128. https://doi.org/10.1021/bk-2005-0914.ch007

[194] Rostrup-Nielsen, J. (2003) Hydrogen Generation by Catalysis. In: Horvath, I.T., Ed., Encyclopedia of Catalysis, Wiley Interscience, 4.

[195] Song, C.S. (2002) Fuel Processing for Low-Temperature and High-Temperature Fuel Cells: Challenges, and Opportunities for Sustainable Development in the 21st Century. Catalysis Today, 77, 17-49. https://doi.org/10.1016/S0920-5861(02)00231-6

[196] Twigg, M.W. (Ed.) (1989) Catalyst Handbook. Wolfe Publishing Ltd., London.

[197] Hoogers, G. (2003) Fuel Cell Technology Handbook. CRC Press, Boca Raton, 5-1-5-23.

[198] Pietrogrande, P. and Bezzeccheri, M. (1993) Chap. 4, Fuel Processing. In: Blomen, L.J.M.J. and Mugerwa, M.N., Eds., Fuel Cell Systems, Plenum Press, New York, 121-151.

[199] Krumpelt, M., Krause, T.R., Carter, J.D., Kopasz, J.P. and Ahmed, S. (2002) Fuel Processing for Fuel Cell Systems in Transportation and Portable Power Applications. Catalysis Today, 77, 3-16. https://doi.org/10.1016/S0920-5861(02)00230-4

[200] Aasberg-Petersen, K., Dybkjær, I., Ovesen, C.V., Schjødt, N.C., Sehested, J. and Thomsen, S.G. (2011) Natural Gas to Synthesis Gas-Catalysts and cataLytic Processes. Journal of Natural Gas Science and Engineering, 3, 423-459. https://doi.org/10.1016/j.jngse.2011.03.004

[201] Adris, A.M. and Pruden, B.B. (1996) On the Reported Attempts to Radically Improve the Performance of the Steam Methane Reforming Reactor. Canadian Journal of Chemical Engineering, 74, 177-186. https://doi.org/10.1002/cjce.5450740202

[202] Kolb, G., Zapf, R., Hessel, V. and Lowe, H. (2004) Propane Steam Reforming in Microchannels-Results from Catalyst Screening and Optimization. Applied Catalysis A: General, 227, 155-166. https://doi.org/10.1016/j.apcata.2004.09.007

[203] Wang, Y., Chin, Y., Rozmiarek, R.T., Johnson, B.R., Gao, Y., Watson, J.M., Tonkovich, A.Y. and Vanderwiel, D.P. (2004) Highly Active and Stable Rh/ $\mathrm{MgOAl}_{2} \mathrm{O}_{3}$ Catalysts for Methane Steam Reforming. Catalysis Today, 98, 575-581. https://doi.org/10.1016/j.cattod.2004.09.011

[204] Song, H., Zhang, L. and Ozkan, U.S. (2007) Effect of Synthesis Parameters on the Catalytic Activity of $\mathrm{Co}-\mathrm{ZrO}_{2}$ for Bio-Ethanol Steam Reforming. Green Chemistry, 9, 686-694. https://doi.org/10.1039/B615087J

[205] Song, H., Zhang, L., Watson, R.B., Braden, D. and Ozkan, U.S. (2007) Investigation of Bio-Ethanol Steam Reforming over Cobalt-Based Catalysts. Catalysis Today, 129, 346-354. https://doi.org/10.1016/j.cattod.2006.11.028

[206] Rostrup-Nielsen, J.R. (1973) Activity of Nickel Catalysts for Steam Reforming of Hydrocarbons. Journal of Catalysis, 31, 173-199. https://doi.org/10.1016/0021-9517(73)90326-6

[207] Wei, J. and Iglesia, E. (2004) Mechanism and Site Requirements for Activation and Chemical Conversion of Methane on Supported Pt Clusters and Turnover Rate Comparisons among Noble Metals. The Journal of Physical Chemistry B, 108, 4094-4103. https://doi.org/10.1021/jp036985z

[208] Ross, J.R.H., Roberts, M.W. and Thomas, J.M. (1974) Specialist Periodical Report. In: Surface and Defect Properties of Solids, The Chemical Society, London, Vol. 4, p. 34 . 
[209] McHugh, K. (2005) Hydrogen Production Methods. MPR Associates Inc., 41.

[210] Rostrup-Nielsen, J.R. (2001) Conversion of Hydrocarbons and Alcohols for Fuel Cells. Physical Chemistry Chemical Physics, 3, 283-288. https://doi.org/10.1039/b004660o

[211] Pettersson, L.J. and Westerholm, R. (2001) State of the Art of Multi-Fuel Reformers for Fuel Cell Vehicles: Problem Identification and Research Needs. International Journal of Hydrogen Energy, 26, 243-264. https://doi.org/10.1016/S0360-3199(00)00073-2

[212] Armor, J.N. (1999) The Multiple Roles for Catalysis in the Production of $\mathrm{H}_{2}$. Applied Catalysis A: General, 176, 159-176. https://doi.org/10.1016/S0926-860X(98)00244-0

[213] Schmidt, V.M., Brockerhoff, P., Hohlein, B., Menzer, R. and Stimming, U. (1994) Utilization of Methanol for Polymer Electrolyte Fuel Cells in Mobile Systems. Journal of Power Sources, 49, 299-313. https://doi.org/10.1016/0378-7753(93)01830-B

[214] Takezawa, N. and Iwasa, N. (1997) Steam Reforming and Dehydrogenation of Methanol: Difference in the Catalytic Functions of Copper and Group VIII Metals. Catalysis Today, 36, 45-56. https://doi.org/10.1016/S0920-5861(96)00195-2

[215] Haga, F., Nakajima, T., Miya, H. and Mishima, S. (1997) Catalytic Properties of Supported Cobalt Catalysts for Steam Reforming of Ethanol. Catalysis Letters, 48, 223-227. https://doi.org/10.1023/A:1019039407126

[216] Cavallaro, S. and Freni, S. (1996) Ethanol Steam Reforming in a Molten Carbonate Fuel Cell. A Preliminary Kinetic Investigation. International Journal of Hydrogen Energy, 21, 465-469. https://doi.org/10.1016/0360-3199(95)00107-7

[217] Angeli, S.D., Monteleone, G., Giaconia, A. and Lemonidou, A.A. (2014) State-ofthe-Art Catalysts for $\mathrm{CH}_{4}$ Steam Reforming at Low Temperature. International Journal of Hydrogen Energy, 39, 1979-1997.

https://doi.org/10.1016/j.ijhydene.2013.12.001

[218] Czernikowski, A. (2001) Glidarc Assisted Preparation of the Synthesis Gas from Natural Gas and Waste Hydrocarbons Gases. Oil \& Gas Science and TechnologyRev. IFP, 2, 181-198. https://doi.org/10.2516/ogst:2001018

[219] Timm, D.L. and Onsan, Z.I. (2001) On Board Fuel Conversion for Hydrogen-FuelCell-Driven Vehicles. Catalysis Review, 43, 31-84. https://doi.org/10.1081/CR-100104386

[220] Hohn, K.L. and Schmidt, L.D. (2001) Partial Oxidation of Methane to Syngas at High Space Velocities over Rh-Coated Spheres. Applied Catalysis A: General, 211, 53-68. https://doi.org/10.1016/S0926-860X(00)00835-8

[221] Krummenacher, J.J., West, K.N. and Schmidt, L.D. (2003) Catalytic Partial Oxidation of Higher Hydrocarbons at Millisecond Contact Times: Decane, Hexadecane, and Diesel Fuel. Journal of Catalysis, 215, 332-343. https://doi.org/10.1016/S0021-9517(03)00011-3

[222] Pino, L., Recupero, V., Beninati, S., Shukla, A.K., Hegde, M.S. and Bera, P. (2002) Catalytic Partial-Oxidation of Methane on a Ceria-Supported Platinum Catalyst for Application in Fuel Cell Electric Vehicles. Applied Catalysis A: General, 225, 63-75. https://doi.org/10.1016/S0926-860X(01)00734-7

[223] Halit Eren Figen, E.H., Sema, Z. and Baykara, Z.S. (2018) Effect of Ruthenium Addition on Molybdenum Catalysts for Syngas Production via Catalytic Partial Oxidation of methane in a monolithic reactor. International Journal of Hydrogen Energy, 43, 1129-1138. https://doi.org/10.1016/j.ijhydene.2017.10.173 
[224] Basini, L., Aasberg-Petersen, K., Guarinoni, A. and Stberg, M. (2001) Catalytic Partial Oxidation of Natural Gas at Elevated Pressure and Low Residence Time. Catalysis Today, 64, 9-20. https://doi.org/10.1016/S0920-5861(00)00504-6

[225] Hickman, D.A. and Schmidt, L.D. (1992) Synthesis Gas Formation by Direct Oxidation of Methane over Pt Monoliths. Journal of Catalysis, 138, 267-282. https://doi.org/10.1016/0021-9517(92)90022-A

[226] Hickman, D., Haupfear, E. and Schmidt, L. (1993) Synthesis Gas Formation by Direct Oxidation of Methane over Rh Monoliths. Catalysis Letters, 17, 223-237. https://doi.org/10.1007/BF00766145

[227] Hickman, D.A. and Schmidt, L.D. (1993) Production of Syngas by Direct Catalytic Oxidation of Methane. Science, 259, 343-346.

https://doi.org/10.1126/science.259.5093.343

[228] Nogare, D.D., Degenstein, N.J., Horn, R., Canu, P. and Schmidt, L.D. (2008) Modeling Spatially Resolved Profiles of Methane Partial Oxidation on Rh Foam Catalyst with Detailed Chemistry. Journal of Catalysis, 258, 131-142.

https://doi.org/10.1016/j.jcat.2008.06.006

[229] Nogare, D.D., Degenstein, N.J., Horn, R., Canu, P. and Schmidt, L.D. (2011) Modeling Spatially Resolved Data of Methane Catalytic Partial Oxidation on Rh Foam Catalyst at Different Inlet Compositions and Flowrates. Journal of Catalysis, 277, 134-148. https://doi.org/10.1016/j.jcat.2010.10.020

[230] Onsan, Z.I. and Avci, A.K. (2011) Reactor Design for Fuel Processing. Fuel Cells: Technologies for Fuel Processing. Elsevier, Amsterdam, 451-516. https://doi.org/10.1016/B978-0-444-53563-4.10014-8

[231] Bellows, R.J. (1999) Technical Challenges for Hydrocarbon Fuel Reforming. DOE, Baltimore, MD.

[232] Joensen, F. and Reostrup-Neilsen, J.R. (2002) Conversion of Hydrocarbons and Alcohols for Fuel Cells. Journal of Power Sources, 105, 195-201. https://doi.org/10.1016/S0378-7753(01)00939-9

[233] Muhammad H. R. (2011) Experimental Studies and Modeling of Synthesis Gas Production and Fischer-Tropsch Synthesis. Ph.D. Thesis, Norwegian University of Science and Technology, Trondheim.

[234] Ghosh, S. and De, S. (2005) Thermodynamic Performance Simulation of a Coal Gasification and SOFC Based Combined Cogeneration Plant by Energy and Exergy Analyses. International Journal of Exergy, 2, 366-384. https://doi.org/10.1504/IJEX.2005.007787

[235] Orhan, M.F., Dincer, I. and Rosen, M.A. (2010) Exergoeconomic Analysis of a Thermochemical Copper-Chlorine Cycle for Hydrogen Production Using Specific Exergy Cost (SPECO) Method. Thermochimica Acta, 497, 60-66. https://doi.org/10.1016/j.tca.2009.08.008

[236] Orhan, M.F. (2011) Conceptual Design, Analysis and Optimization of Nuclear-Based Hydrogen Production via Copper-Chlorine Thermochemical cycles. Doctoral Dissertation, University of Ontario Institute of Technology, Oshawa.

[237] Laurendeau, N.M. (1978) Heterogeneous Kinetics of Coal Char Gasification and Combustion. Progress in Energy and Combustion Science, 4, 221-270. https://doi.org/10.1016/0360-1285(78)90008-4

[238] Watanabe, H. and Otaka, M. (2006) Numerical Simulation of Coal Gasification in Entrained Flow Coal Gasifier. Fuel, 85, 1935-1943.

https://doi.org/10.1016/j.fuel.2006.02.002 
[239] Miller, B.G. (2005) Coal Energy Systems. Elsevier, Amsterdam.

[240] Aghahosseini, S., Dincer, I. and Naterer, G.F. (2011) Integrated Gasification and $\mathrm{Cu}-\mathrm{Cl}$ Cycle for Trigeneration of Hydrogen, Steam and Electricity. International Journal of Hydrogen Energy, 36, 2845-2854. https://doi.org/10.1016/j.ijhydene.2010.11.078

[241] Giuffrida, A., Romano, M.C. and Lozza, G. (2011) Thermodynamic Analysis of Air-Blown Gasification for IGCC Applications. Applied Energy, 88, 3949-3958. https://doi.org/10.1016/j.apenergy.2011.04.009

[242] Jordal, K., Anantharaman, R., Peters, T.A., Berstad, D., Morud, J., Nekså, P., et al. (2015) High-Purity $\mathrm{H}_{2}$ Production with $\mathrm{CO}_{2}$ Capture Based on Coal Gasification. Energy, 88, 9-17. https://doi.org/10.1016/j.energy.2015.03.129

[243] Gnanapragasam, N.V., Reddy, B.V. and Rosen, M.A. (2010) Hydrogen Production from Coal Gasification for Effective Downstream $\mathrm{CO}_{2}$ Capture. International Journal of Hydrogen Energy, 35, 4933-4943. https://doi.org/10.1016/j.ijhydene.2009.07.114

[244] Seyitoglu, S.S., Dincer, I. and Kilicarslan, A. (2015) Assessment of an IGCC Based Trigeneration System for Power, Hydrogen and Synthesis Fuel Production. International Journal of Hydrogen Energy, 41, 1-8.

[245] Ozturk, M. and Dincer, I. (2013) Thermodynamic Assessment of an Integrated Solar Power Tower and Coal Gasification System for Multi-Generation Purposes. Energy Conversion and Management, 76, 1061-1072.

https://doi.org/10.1016/j.enconman.2013.08.061

[246] Zhu, L., Zhang, Z., Fan, J. and Jiang, P. (2016) Polygeneration of Hydrogen and Power Based on Coal Gasification Integrated with a Dual Chemical Looping Process: Thermodynamic Investigation. Computers \& Chemical Engineering, 84, 302-312. https://doi.org/10.1016/j.compchemeng.2015.09.010

[247] Liszka, M., Malik, T. and Manfrida, G. (2012) Energy and Exergy Analysis of Hydrogen-Oriented Coal Gasification with $\mathrm{CO}_{2}$ Capture. Energy, 45, 142-150. https://doi.org/10.1016/j.energy.2012.03.054

[248] Al-Zareer, M., Dincer, I. and Rosen, M.A. (2016) Development and Analysis of an Integrated System with Direct Splitting of Hydrogen Sulfide for Hydrogen Production. International Journal of Hydrogen Energy, 41, 20036-20062. https://doi.org/10.1016/j.ijhydene.2016.08.217

[249] Cohce, M.K., Dincer, I. and Rosen, M.A. (2010) Thermodynamic Analysis of Hydrogen Production from Biomass Gasification. International Journal of Hydrogen Energy, 35, 4970-4980. https://doi.org/10.1016/j.ijhydene.2009.08.066

[250] Arabkhalaj, A., Ghassemi, H. and Shahsavan Markadeh, R. (2016) Thermodynamic Evaluation of Integrated Gasification Combined Cycle: Comparison between High-Ash and Low-Ash Coals. International Journal of Energy Research, 40, 1638-1651. https://doi.org/10.1002/er.3541

[251] Al-Zareer, M., Dincer, I. and Rosen, M.A. (2018) Analysis and Assessment of a Hydrogen Production Plant Consisting of Coal Gasification, Thermochemical Water Decomposition and Hydrogen Compression Systems. Energy Conversion and Management, 157, 600-618. https://doi.org/10.1016/j.enconman.2017.11.047

[252] Lynum, S. (1994) $\mathrm{CO}_{2}$-Free Hydrogen from Hydrocarbons-The Kvaerner CB\&H Process. 10th World Hydrogen Energy Conference, Cocoa Beach, FL, June 1994.

[253] Yan, W. and Hoekman, K. (2014) Production of $\mathrm{CO}_{2}$-Free Hydrogen from Methane Dissociation: A Review. Environmental Progress \& Sustainable Energy, 33, 213-219. https://doi.org/10.1002/ep.11746 
[254] Ashik, U.P.M., Wan Daud, W.M.A. and Abbas, H.F. (2015) Production of Greenhouse Gas Free Hydrogen by Thermocatalytic Decomposition of Methane-A Review. Renewable and Sustainable Energy Reviews, 44, 221-256. https://doi.org/10.1016/j.rser.2014.12.025

[255] Gaudernack, B. and Lynum, S. (1998) Hydrogen from Natural Gas without Release of $\mathrm{CO}_{2}$ to the Atmosphere. International Journal of Hydrogen Energy, 23, 1087-1093. https://doi.org/10.1016/S0360-3199(98)00004-4

[256] Damen, K., Van Troost, M., Faaij, A. and Turkenburg, W. (2006) A Comparison of Electricity and Hydrogen Production Systems with $\mathrm{CO}_{2}$ Capture and Storage, Part A: Review and Selection of Promising Conversion and Capture Technologies. Progress in Energy and Combustion Science, 32, 215-246. https://doi.org/10.1016/j.pecs.2005.11.005

[257] Agrafiotis, C., Von Storch, H., Roeb, M. and Sattler, C. (2014) Solar Thermal Reforming of Methane Feedstocks for Hydrogen and Syngas Production-A Review. Renewable and Sustainable Energy Reviews, 29, 656-682. https://doi.org/10.1016/j.rser.2013.08.050

[258] Baykara, S.Z. and Bilgen, E. (1985) Synhesis Gas and $\mathrm{H}_{2}$ Production from Solar Gasification of Albertan Coal. Energy Conversion and Management, 25, 391-398. https://doi.org/10.1016/0196-8904(85)90002-0

[259] Zeng, K., Gauthier, D., Soria, J., Mazza, G. and Flamant, G. (2017) Solar Pyrolysis of Carbonaceous Feedstocks: A Review. Solar Energy, 156, 73-92.

https://doi.org/10.1016/j.solener.2017.05.033

[260] Coelho, B., Oliveira, A.C. and Mendes, A. (2010) Concentrated Solar Power for Renewable Electricity and Hydrogen Production from Water-A Review. Energy \& Environmental Science, 3, 1398-1405. https://doi.org/10.1039/b922607a

[261] Steinfeld, A. (2005) Solar Thermochemical Production of Hydrogena Review. Solar Energy, 78, 603-615. https://doi.org/10.1016/j.solener.2003.12.012

[262] Jucks, W. and Sandhoff, A.G. (1980) Theory of Coal Pyrolysis. The Pennsylvania State College, State College, Penna, 567-569.

[263] Collot, A.-G. (2002) Matching Gasifiers to Coals. IEA Clean Coal Centre, October 2002.

[264] Wu, W. and Yoshikawa, K. (2002) R\&D on Micro-pyrolyzer for Solid Wastes Using High Temperature Steam and Air. JSME International Journal Series B-Fluids and Thermal Engineering, 45, 487-491. https://doi.org/10.1299/jsmeb.45.487

[265] Demirbas, A. and Arin, G. (2004) Hydrogen from Biomass via Pyrolysis: Relationships between Yield of Hydrogen and Temperature. Energy Sources, 26, 1061-1069. https://doi.org/10.1080/00908310490494568

[266] Demirbas, A. (2005) Recovery of Chemicals and Gasoline-Range Fuels from Plastic Wastes via Pyrolysis. Energy Sources, 27, 1313-1319. https://doi.org/10.1080/009083190519500

[267] Jin, Y.Z., Gao, C., Hsu, W.K., Zhu, Y.Q., Huczko, A., Bystrzejewski, M., Roe, M., Lee, C.Y., Acquah. S., Kroto. H. and Walton, D.R.M. (2005) A Systematic Study of the Large-Scale Synthesis and Characterization of Carbon Spheres Prepared By Direct Pyrolysis of Hydrocarbons. Carbon, 43, 1944-1953. https://doi.org/10.1016/j.carbon.2005.03.002

[268] Karaeva, A.P., Mordkovich, V.Z. and Tretyakov, V.F. (2005) Production of Carbonanofibers and Nanotubes by Catalytic Pyrolysis of Methane. Solid Fuel Chemistry, 39, 61-76. 
[269] Muradov, N. (2003) Emission-Free Fuel Reformers for Mobile and Portable Fuel Cell Applications. Journal of Power Sources, 118, 320-324. https://doi.org/10.1016/S0378-7753(03)00078-8

[270] Liu, C.J., Xu, G.H. and Wang, T. (1999) Non-Thermal Plasma Approaches in $\mathrm{CO}_{2}$ Utilization. Fuel Process, 58, 119-134. https://doi.org/10.1016/S0378-3820(98)00091-5

[271] Locke, B.R., Sato, M., Sunka, P., Hoffmann, M.R. and Chang, J.S. (2006) Electrohydraulic Discharge and Nonthermal Plasma for Water Treatment. Industrial \& Engineering Chemistry Research, 45, 882-905. https://doi.org/10.1021/ie050981u

[272] Du, C., Mo, J. and Li, H. (2015) Renewable Hydrogen Production by Alcohols Reforming Using Plasma and Plasma-Catalytic Technologies: Challenges and Opportunities. Chemical Reviews, 115, 1503-1542. https://doi.org/10.1021/cr5003744

[273] Bromberg, L., Cohn, D.R., Rabinovich, A. and Alexeev, N. (2001) Hydrogen Manufacturing Using Low Current, Non-Thermal Plasma Boosted Fuel Converters. PSFC/RR-01-1.

[274] Bromberg, L., Cohn, D.R., Rabinovich, A. and Alexeev, N. (1999) Plasma Catalytic Reforming of Methane. International Journal of Hydrogen Energy, 24, 1131-1137. https://doi.org/10.1016/S0360-3199(98)00178-5

[275] Boulos, M.I. (1996) New Frontiers in Thermal Plasma Processing. Pure and Applied Chemistry, 68, 1007-1010. https://doi.org/10.1351/pac199668051007

[276] Min, T. and Yoshikawa, K. (2004) Performance Demonstration of Dual-Fueled Diesel Engine Combine with a Gasifier of Solid Wastes. Paper presented at the $23 \mathrm{rd}$ International Conference on Incineration and Thermal Treatment Technologies, Phoenix, Arizona.

[277] Inaba, T., Nagano, M. and Endo, M. (1999) Investigation of Plasma Treatment for Hazardous Wastes Such As Fly Ash and Asbestos. Electrical Engineering in Japan, 126, 831-838. https://doi.org/10.1002/(SICI)1520-6416(199902)126:3<73::AID-EEJ8>3.0.CO;2-J

[278] Park, H.S., Lee, B.J. and Kim, S.J.J. (2006) Characteristics of PE Gasification by Steam Plasma. Journal of Industrial and Engineering Chemistry, 12, 216-223.

[279] Ye, G.Z., Burstrom, E., Kuhn, M. and Piret, J. (2003) Reduction of Steel-Making Slags for Recovery of Valuable Metals and Oxide Materials. Scandinavian Journal of Metallurgy, 32, 7-14. https://doi.org/10.1034/j.1600-0692.2003.00526.x

[280] Ramachandran, K. and Kikukawa, N. (2002) Thermal Plasma In-Flight Treatment of Electroplating Sludge. IEEE Transactions on Plasma Science, 30, 310-317. https://doi.org/10.1109/TPS.2002.1003875

[281] Nishikawa, H., Ibe, M., Tanaka, M., Ushio, M., Takemoto, T., Tanaka, K., Tanahashi, N. and Ito, T. (2004) A Treatment of Carbonaceous Wastes Using Thermal Plasma with Steam. Vacuum, 73, 589-593. https://doi.org/10.1016/j.vacuum.2003.12.074

[282] Cubas, A.L.V., Souza, I.G., Debacher, N.A. and Carasek, E. (2005) Development of a DC-Plasma Torch Constructed with Graphite Electrodes and an Integrated Nebulization System for Decomposition of $\mathrm{CCl}_{4}$. Journal of the Brazilian Chemical Society, 16, 531-534. https://doi.org/10.1590/S0103-50532005000400006

[283] Galeno, G., Minutillo, M. and Perna, A. (2011) From Waste to Electricity through Integrated Plasma Gasification/Fuel Cell (IPGFC) System. International Journal of Hydrogen Energy, 36, 1692-1701. https://doi.org/10.1016/j.ijhydene.2010.11.008

[284] Gomez, E., Rani, D.A., Cheeseman, C.R., Deegan, D., Wise, M. and Boccaccini, A.R. 
(2009) Thermal Plasma Technology for the Treatment of Wastes: A Critical Review. Journal of Hazardous Materials, 161, 614-626. https://doi.org/10.1016/j.jhazmat.2008.04.017

[285] Tsai, H.L., Wang, C.S. and Lee, C.H. (2008) Hydrogen Production in a Thermal Plasma Hydrogen Reformer Using Ethanol Steam Reforming. Journal of the Chinese Institute of Engineers, 31, 417-425. https://doi.org/10.1080/02533839.2008.9671396

[286] Paulmier, T. and Fulcheri, L. (2005) Use of Non-Thermal Plasma for Hydrocarbon Reforming. Chemical Engineering Journal, 106, 59-71.

https://doi.org/10.1016/j.cej.2004.09.005

[287] Bromberg, L., Cohn, D.R. and Rabinovich, A. (1997) Plasma Reformer-Fuel Cell System for Decentralized Power Applications. International Journal of Hydrogen Energy, 22, 83-94. https://doi.org/10.1016/0360-3199(95)00121-2

[288] Petitpas, G., Rollier, J.D., Darmon, A., Gonzalez-Aguilar, J., Metkemeijer, R. and Fulcheri, L. (2007) A Comparative Study of Non-Thermal Plasma Assisted Reforming Technologies. International Journal of Hydrogen Energy, 32, 2848-2867. https://doi.org/10.1016/j.ijhydene.2007.03.026

[289] Bouamra, K., Simiand, N.B., Jorand, F., Pasquiers, S. and Postel, C. (2003) Decomposition of Isooctane Using a Dielectric Barrier Discharge. 16th International Symposium on Plasma Chemistry, Taormina, 22-27 June 2003.

[290] Sobacchi, M.G., Saveliev, A.V., Fridman, A.A., Kennedy, L.A., Ahmed, S. and Krause, T. (2002) Experimental Assessment of a Combined Plasma/Catalytic System for Hydrogen Production via Partial Oxidation of Hydrocarbon Fuels. International Journal of Hydrogen Energy, 27, 635-642. https://doi.org/10.1016/S0360-3199(01)00179-3

[291] Kappes, T., Schiene, W. and Hammer, T. (2002) Energy Balance of a Dielectric Barrier Discharge for Hydrocarbon Steam Reforming. 8th International Symposium of High Pressure Low Temperature Plasma Chemistry, Pyhajarve, Estonia.

[292] Bromberg, L., Cohn, D.R., Rabinovich, A., Alexeev, N., Samokhin, N. and Hadidi, K. (2006) On-Board Plasmatron Hydrogen Production for Improved Vehicles. PSFC JA06-03.

[293] Iskenderova, K., Porshnev, P., Gutsol, A., Saveliev, A., Fridman, A. and Kennedy, L. (2001) Methane Conversion into Syn-Gas in Gliding Arc Discharge. 15th International Symposium on Plasma Chemistry, Orleans, 9-13 July 2001.

[294] Kalra, C.S., Gutsol, A.F. and Fridman, A.A. (2005) Gliding Arc Discharges as a Source of Intermediate Plasma for Methane Partial Oxidation. IEEE Transactions on Plasma Science, 33, 32-41.

[295] Ahmar, E.E., Met, C., Aubry, O., Khacef, A. and Cormier, J.M. (2006) Hydrogen Enrichment of a Methane-Air Mixture by Atmospheric Pressure Plasma for Vehicle Applications. Chemical Engineering Journal, 116, 13-18. https://doi.org/10.1016/j.cej.2005.10.005

[296] Sekiguchi, H. and Mori, Y. (2003) Steam Plasma Reforming Using Microwave Discharge. Thin Solid Films, 435, 44-48. https://doi.org/10.1016/S0040-6090(03)00379-1

[297] Rusanov, V., Babaritskii, A., Gerasimov, E., Deminskii, M., Demkin, S., Zhivotov, V., et al. (2003) Stimulation of the Partial Oxidation of Methane in a Microwave Discharge. Doklady Physics, 48, 119-122. https://doi.org/10.1134/1.1565615

[298] Babaritskii, A.I., Baranov, I.E., Bibikov, M.B., Demkin, S.A., Zhivotov, V.K., Konovalov, G.M., et al. (2004) Partial Hydrocarbon Oxidation Processes Induced by 
Atmospheric-Pressure Microwave-Discharge Plasma. High Energy Chemistry, 38, 407-411. https://doi.org/10.1023/B:HIEC.0000048240.92448.f2

[299] Cormier, J.M. and Rusu, I. (2001) Syngas Production via Methane Steam Reforming with Oxygen: Plasma Reactors versus Chemical Reactors. Journal of Physics D: Applied Physics, 34, 2798-2803. https://doi.org/10.1088/0022-3727/34/18/313

[300] Sekine, Y., Asai, S., Urasaki, K., Kado, S., Kikuchi, E. and Matsukata, M. (2003) Development of Liquid Fuel Reformer Using Low Energy Pulse Discharge at Room Temperature. 16th International Symposium on Plasma Chemistry, Taormina, 22-27 June 2003.

[301] Ouni, F., Khacef, A. and Cormier, J.M. (2005) Methane Steam Reforming with Oxygen in a Sliding Discharge Reactor. 17 th International Symposium on Plasma Chemistry, Toronto.

[302] Bromberg, L. and Rabinovich, A. (2001) Homogeneous Charge Compression Ignition Control by the Use of Plasmatron Fuel Converter Technology. PSFC/JA-01-18.

[303] Bromberg, L., Cohn, D.R. and Hadidi, K. (2005) Plasmatron Reformation of Renewable Fuels. PSFC/JA-05-03.

[304] Aubry, O., Met, C., Khacef, A. and Cormier, J.M. (2005) On the Use of a Non-Thermal Plasma Reactor for Ethanol Steam Reforming. Chemical Engineering Journal, 106, 241-247. https://doi.org/10.1016/j.cej.2004.12.003

[305] Czernikowski, A., Czernikowski, M. and Wesolowska, K. (2003) Glidarc-Assisted Production of Synthesis Gas from Rapeseed Oil. 1st European Hydrogen Energy Conference, Grenoble.

[306] Yan, Z., Chen, L. and Wang, H. (2006) Hydrogen Generation from reforMing of Lower Alcohols Aqueous Solution by Glow Discharge Plasma under Liquid. Journal of Chemical Industry and Engineering (China), 57, 1432-1437.

[307] Hammer, T., Kappes, T. and Baldauf, M. (2004) Plasma Catalytic Hybrid Processes: Gas Discharge Initiation and Plasma Activation of Catalytic Processes. Catalysis Today, 89, 5-14. https://doi.org/10.1016/j.cattod.2003.11.001

[308] Biniwale, R.B., Mizuno, A. and Ichikawa, M. (2004) Hydrogen Production by Reforming of Iso-Octane Using Spray-Pulsed Injection and Effect of Non-Thermal Plasma. Applied Catalysis A: General, 276, 169-177. https://doi.org/10.1016/j.apcata.2004.08.003

[309] O’Brien, C.J., Hochgreb, S., Rabinovich, A., Bromberg, L. and Cohn, D.R. (1996) Hydrogen Production via Plasma Reformers. In: Proceedings of the Intersociety Energy Conversion Engineering Conference, IEEE, Piscataway, NJ/Washington, DC, $1747-1752$.

[310] Mutaf-Yardimci, O., Saveliev, A.V., Fridman, A.A. and Kennedy, L.A. (1998) Employing Plasma as Catalyst in Hydrogen Production. International Journal of $\mathrm{Hy}^{-}$ drogen Energy, 23, 1109-1111. https://doi.org/10.1016/S0360-3199(98)00005-6

[311] Matsui, Y., Kawakami, S., Takashima, K., Katsura, S. and Mizuno, A. (2005) Liquid-Phase Fuel Re-Forming at Room Temperature Using Nonthermal Plasma. Energy and Fuels, 19, 1561-1565. https://doi.org/10.1021/ef0497816

[312] Bromberg, L., Cohn, D.R., Rabinovich, A., Alexeev, N., Samokhin, A., Hadidi, K., Palaia, J. and Margarit-Bel, N. (2006) Onboard Plasmatron Hydrogen Production for Improved Vehicles. MIT Plasma Science \& Fusion Center Research Report PSFC JA-06-3.

[313] Czernichowski, A., Czernichowski, P. and Wesolowska, K. (2004) Fuel Cell Science, Engineering and Technology-2004, Plasma-Catalytical Partial Oxidation of Various 
Carbonaceous Feeds into Synthesis Gas. American Society of Mechanical Engineers, New York/Rochester, NY, 669-676.

[314] Jiang, T., Li, Y., Liu, C.-J., Xu, G.-H., Eliasson, B. and Xue, B. (2002) Plasma Methane Conversion Using Dielectric-Barrier Discharges with Zeolite A. Catalysis Today, 72, 229-235. https://doi.org/10.1016/S0920-5861(01)00497-7

[315] Moisan, M., Sauve, G., Zakrzewski, Z. and Hubert, J. (1994) An Atmospheric Pressure Waveguide-Fed Microwave Plasma Torch: The TIA Design. Plasma Sources Science and Technology, 3, 584-592. https://doi.org/10.1088/0963-0252/3/4/016

[316] Kambara, S., Hayakawa, Y., Masui, M., Miura, T., Kumabe, K. and Moritomi, H. (2012) Relation between Chemical Composition of Dissociated Ammonia by Atmospheric Plasma and DeNOx Characteristics. Transactions of the JSME, Series B, 78, 1038-1042. https://doi.org/10.1299/kikaib.78.1038

[317] Hayakawa, Y., Kambara, S. and Miura, T. (2015) Ammonia Reforming by DBD Using a Hydrogen Permeable Membrane. Proceedings of the 68 th Gaseous Electronics Conference, CD-ROM No.KW1.00003.

[318] Kambara, S., Hayakawa, Y., Inoue, Y. and Miura, T. (2016) Hydrogen Production from Ammonia Using Plasma Membrane Reactor. Journal of Sustainable Development of Energy, Water and Environment Systems, 4, 193-202.

https://doi.org/10.13044/j.sdewes.2016.04.0016

[319] Sieverts, A. and Krumbhaar, W. (1910) Solubility of Gases in Metals and Alloys. Berichte der Deutschen Chemischen Gesellschaft, 43, 893-900. https://doi.org/10.1002/cber.191004301152

[320] Hayakawa, Y., Miura, T., Shizuya, K., Wakazono, S., Tokunaga, K. and Kambara, S. (2018) Hydrogen Production System Using a Plasma Membrane Reactor. 9th International Conference on Hydrogen Production (ICH2P-2018). (Under Publication)

[321] Rozmiarek, B. (2008) Hydrogen Generation from Biomass-Derived Carbohydrates via Aqueous Phase Reforming Process Virent Energy Systems, Inc, U.S. Department of Energy, Washington DC, PD-6.

[322] Sørensen, B. (2005) Hydrogen and Fuel Cells Emerging Technologies and Applications. Elsevier Academic Press, New York, 450.

[323] Call, D. and Logan, B.E. (2008) Hydrogen Production in a Single Chamber Microbial Electrolysis Cell Lacking a Membrane. Environmental Science and Technology, 42, 3401-3406. https://doi.org/10.1021/es8001822 